\title{
Effects of atmospheric cold fronts on stratification and water quality of a tropical reservoir: implications for aquaculture
}

\author{
Carlos A. S. Araújo 1,6,*, Fernanda G. Sampaio ${ }^{2}$, Enner Alcântara ${ }^{3}$, \\ Marcelo P. Curtarelli ${ }^{4}$, Igor Ogashawara ${ }^{5}$, José L. Stech ${ }^{1}$ \\ ${ }^{1}$ Remote Sensing Division, National Institute for Space Research, 12227-010 São José dos Campos, SP, Brazil \\ ${ }^{2}$ Embrapa Environment, Brazilian Agricultural Research Corporation, 13820-000 Jaguariúna, SP, Brazil \\ ${ }^{3}$ Department of Environmental Engineering, São Paulo State University, 12247-004 São José dos Campos, SP, Brazil \\ ${ }^{4}$ Green Economy Center, Reference Center Foundation for Innovative Technologies, 88040-970 Florianópolis, SC, Brazil \\ ${ }^{5}$ Department of Earth Sciences, Indiana University-Purdue University Indianapolis, Indianapolis, IN 46202, USA \\ ${ }^{6}$ Present address: Département de Biologie, Chimie et Géographie, Université du Québec à Rimouski, Rimouski, \\ QC G5L 3A1, Canada
}

\begin{abstract}
Stratification and mixing patterns of a water body are influenced by the variability of atmospheric systems, which can also modify their biogeochemical properties. The primary goal of this study was to analyze the effect of atmospheric cold fronts (CFs) on thermal stratification and water quality parameters in 4 embayments of the Furnas Hydroelectric Reservoir (FHR) (southeastern Brazil), a warm monomictic water body. A secondary goal was to evaluate the implications of this effect on the aquaculture of Nile tilapia Oreochromis niloticus (L.) in net cages. A 2 yr dataset of meteorological and water quality parameters was used to compute heat flux balance components and buoyancy frequency. These parameters were used to evaluate the influence of CFs on FHR water column stability and water quality. It was observed that the passing of CFs increased net heat loss and wind velocity, resulting in a partial mixture of surface waters with deeper layers. These changes in the physical structure of the water column altered the diel cycle of water temperature, led to a slight decrease in dissolved oxygen concentrations and $\mathrm{pH}$ values during the stratification period, and contributed to the increase in dilution power at the fish cultivation sites. However, following CF passages, no significant changes were observed in water quality parameters that influenced Nile tilapia cultivation in the FHR. Nevertheless, the understanding of meteorological systems and their influence on the physical and biogeochemical properties of an aquatic system is important for optimal management of aquaculture activities.
\end{abstract}

KEY WORDS: Tropical reservoir - Cold fronts - Water quality parameters · Aquaculture . Nile tilapia

\section{INTRODUCTION}

Worldwide consumption of fish is increasing, and aquaculture has been identified as the main supplier for this demand, considering that wild fisheries captures have not increased in the past 10 yr (FAO 2016).

${ }^{*}$ Corresponding author:

carlosalberto.sampaiodearaujo@uqar.ca
In Brazil, the increase in aquaculture production follows the worldwide trend. The production of freshwater aquaculture grew at a mean rate of approximately $27 \% \mathrm{yr}^{-1}$ between 2009 and 2011 (MPA 2013). Brazilian aquaculture activities produced around 483241 tons of fish in 2015 (IBGE 2016). One of the

(C) The authors 2017. Open Access under Creative Commons by Attribution Licence. Use, distribution and reproduction are unrestricted. Authors and original publication must be credited. 
major products is the exotic Nile tilapia Oreochromis niloticus (L.), making up $45.4 \%$ of total Brazilian finfish aquaculture production in 2015 (IBGE 2016).

To increase the freshwater aquaculture production for food supply, aquatic systems such as lakes and reservoirs have been hosting fish farming activities. Brazil has $>250$ reservoirs that could host such activities. However, these activities may lead to environmental problems such as eutrophication and changes in ecological succession. Although the increase in aquaculture production is important to assure food security, an environmental monitoring protocol is necessary to ensure environmental and human health as well as support policymakers' decisions. An analysis of the possible impacts of aquaculture on these reservoirs is required for the management of aquaculture activities.

Changes in the physical and biogeochemical properties of a water column, as well the associated implications to aquatic life caused by the succession of different meteorological systems over tropical reservoirs, have been studied in different regions of Brazil (Tundisi et al. 2004, 2010, Curtarelli et al. 2013, $2014 a, b)$. These changes occur mainly because of variation in the heat budget of the aquatic system, which is primarily modulated by seasonal cycles of incoming shortwave radiation and other meteorological variables along with mesoscale atmospheric disturbances. Among the meteorological systems over South America, cold front (CF) incursions are one of the most recurrent atmospheric systems. CFs influence atmospheric circulation, precipitation, and temperature regime (Garreaud 2000). Moreover, they are also responsible for quick variations in the heat budget of aquatic systems (Liu et al. 2009, Alcântara et al. 2010, Curtarelli et al. 2013).

Several studies have shown a relationship between $\mathrm{CF}$ passages and changes in the physical properties of the water column at continental shelves (Stech \& Lorenzzetti 1992) and reservoirs (Tundisi et al. 2004, Alcântara 2012, Curtarelli et al. 2013, 2014a). These changes are important for the vertical distribution of chemical constituents, which are crucial factors to estimate primary productivity in aquatic systems (Ganf 1974, Reynolds 1992, Serra et al. 2007, Vidal et al. 2010). Thus, processes that alter water column stability such as stratification and mixing are important for understanding phytoplankton population dynamics, diversity, and succession (Reynolds 1992, Calijuri et al. 2002, Becker et al. 2009a,b).

$\mathrm{CF}$ effects on water column stability and phytoplankton succession have been studied in a Brazilian tropical reservoir by Tundisi et al. (2004). They showed that alterations in the periods of vertical stratification and mixing were related to the passage and dissipation of CFs. Based on these observations, a framework was proposed for the management of lakes and reservoirs in southeastern Brazil. This framework relates the instability in the water column caused by the mixing process during a $\mathrm{CF}$ passage to the dominance of diatoms and green algae. Water column stability, which is caused by the stratification process in the absence of $\mathrm{CFs}$, is related to cyanobacterial dominance periods (Tundisi et al. 2010).

The succession of mixing and stratification processes, often related to meteorological systems, is an important driver for environmental parameters such as phytoplankton abundance, water transparency, and dissolved oxygen (DO) levels (van Rijssel et al. 2016). Even still, the use of these stability processes in understanding their relation to higher-ranking levels of the trophic chain has not yet been totally explored. In addition, little or no information is available regarding $\mathrm{CFs}^{\prime}$ effects on water quality parameters (WQPs) in aquaculture fields.

Since atmospheric radiation and air temperature are controlling factors for water column temperature, it is important to understand the role of CF passages over aquaculture fields. Such water column changes can affect the productivity and growth of fisheries (Kapetsky 2000). Therefore, the identification of water column changes can equip aquaculture management toward improving production and preventing environmental degradation.

From an aquaculture perspective, the maintenance of an ideal range for parameters such as temperature, $\mathrm{DO}$, and $\mathrm{pH}$ are fundamental. Variations in WQPs affect fish by triggering their stress disruption, which can increase susceptibility to disease and cause a decrease in production. One example is the relationship between water temperature and DO consumption, which shows that, in warmer waters, DO consumption is higher (Boyd \& Pillai 1985). It has also been found that low DO levels cause changes in the behavior, physiology, and morphology of fish (Pollock et al. 2007), and temperature also affects the chemical and biological processes of aquatic organisms' metabolism (Boyd \& Pillai 1985). Changes in water temperature modify fish metabolism, resulting in a high-energy demand for maintenance and less energy available for growth (Jobling 1994).

We hypothesized that changes in wind pattern, heat flux balance, and the stratification-to-mixing conditions caused by a CF passage will affect WQPs to be outside the optimal range of environmental conditions for aquaculture. The aim of this work was 
to understand the role of CF passages over inland water fish farms located in a region of the Furnas Hydroelectric Reservoir (FHR; see Fig. 1), Guapé, Brazil. The specific objectives were to (1) identify the seasonal patterns of stratification and mixing processes in the FHR, (2) identify the frequency of the passage of CFs over the FHR, (3) quantify the changes in water temperature and in heat flux balance based on normal meteorological conditions, (4) understand how the water column stability changes with $\mathrm{CF}$ passages, and (5) compare changes in critical WQPs to the optimal ranges for Nile tilapia farming.

\section{MATERIALS AND METHODS}

\section{Study site}

FHR is in the middle course of the Grande River, Minas Gerais State, Brazil (Fig. 1), and it is formed mainly by 2 rivers: the Grande River, flowing in an east-west direction, and the Sapucaí River, flowing in a southeast-northwest direction. The flooded area and the storage capacity at its maximum level at $768 \mathrm{~m}$ above mean sea level (a.m.s.1.) are $1440 \mathrm{~km}^{2}$ and 22.95 billion $\mathrm{m}^{3}$ of water, respectively. FHR's useful volume is 17.22 billion $\mathrm{m}^{3}$ of water and its minimum operational level is at $750 \mathrm{~m}$ a.m.s.l. (Furnas 2016). Based on its bathymetry, FHR reaches a maximum depth of $90 \mathrm{~m}$ and has a mean depth of $16 \mathrm{~m}$.

FHR is surrounded by 23 municipalities, 19 of which produced $4683-5130$ tons $\mathrm{yr}^{-1}$ of Nile tilapia from 2013 to 2015. In Guapé municipality, Nile tilapia production was 2430,1500, and 790 tons $\mathrm{yr}^{-1}$ for the years 2013, 2014, and 2015, respectively (IBGE 2016). This intense decrease in fish production was related to a constant and pronounced reservoir level fluctuation and the difficulty of regularizing the aquaculture activity in the area. Fish diseases were not a significant cause for this decrease, since reported cases were usually caused by the transport of fingerlings. However, occasional occurrences of Streptococcus and columnaris were observed in fish under production (Cardoso et al. 2013).

Selected areas for this study were 4 small embayments (Fig. 1C), located near the municipality of Guapé where there was an intensive cage cultivation of Nile tilapia. At the time of this study, there were $>200$ Nile tilapia producers in the FHR, though we focused on 11 fish farms (with a total cage volume of about $817-818 \mathrm{~m}^{3}$ ), which have been active for the last $7 \mathrm{yr}$. They produce around 1000 tons $\mathrm{yr}^{-1}$ in 1.4 cycles $\mathrm{yr}^{-1}$, with an individual commercial size between 0.85 and $1.00 \mathrm{~kg}$. Fish farms have newly hatched, young, and adult Nile tilapia, even though most of the producers $(52.4 \%)$ do not adopt any management practices, such as measuring fish weight and length (Cardoso et al. 2013).

\section{Moored platforms}

Six platforms were anchored within the study area (Fig. 1C). One was equipped with meteorological
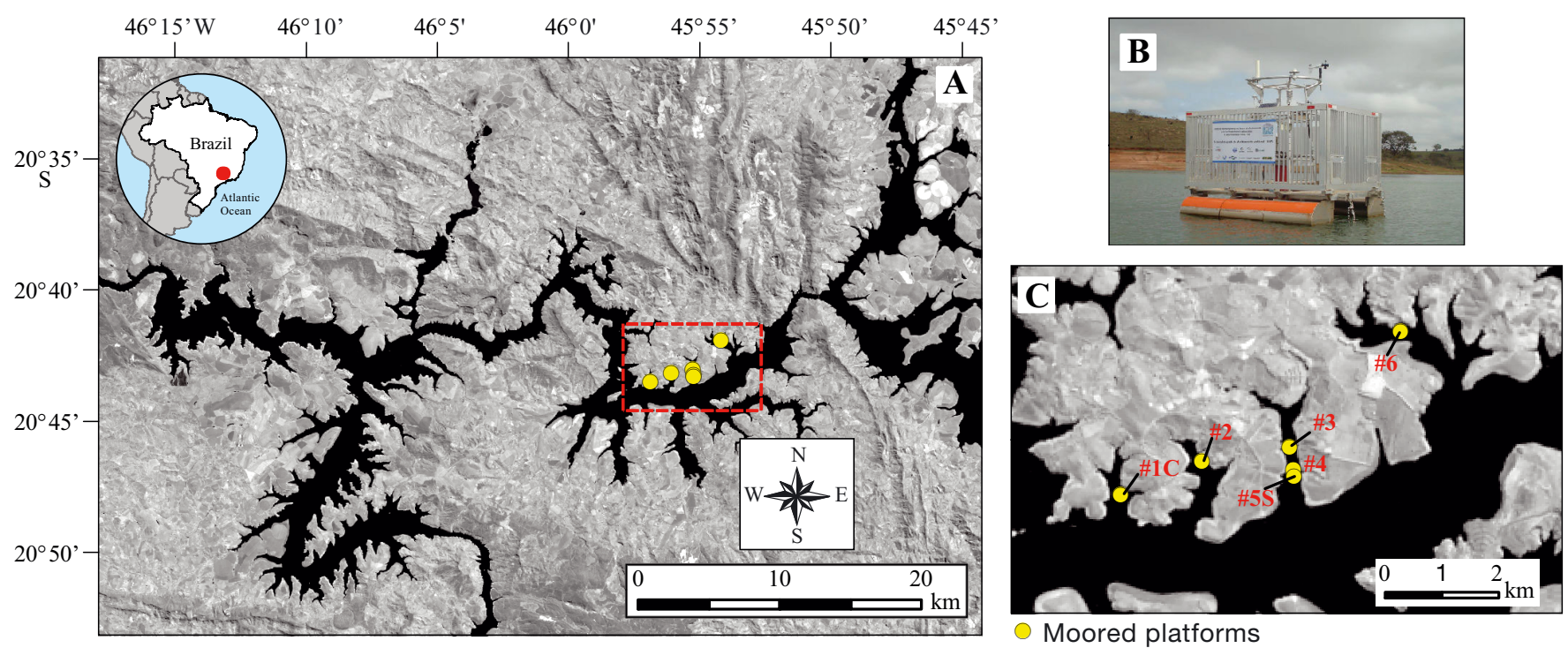

Fig. 1. (A) Furnas Hydroelectric Reservoir (red dot in inset) in Brazil and location of monitoring platforms (yellow dots). (B) Integrated System for Environmental Monitoring (SIMA) at platform \#5S. (C) Zoom-in of red dashed box in (A) with the 6 moored platforms shown. Images in $(\mathrm{A}, \mathrm{C})$ from Landsat 8 OLI, near-infrared band, August 3, 2014 
and water quality sensors ( $\# 5 \mathrm{~S}$; Fig. 1B), while the other 5 have only water quality sensors (\#1C, \#2, \#3, $\# 4$, and \#6). Platform \#1C was placed in an area free of Nile tilapia cages to serve as a control site, while \#2 was in an embayment in which a fish farm trader association produces around 150 tons $\mathrm{yr}^{-1}$. Platforms $\# 3$, \#4, and \#5S were placed in an embayment where there were 9 producers totaling a production of around 500 tons $\mathrm{yr}^{-1}$. Finally, platform \#6 was in an embayment with 1 fish farm which has a yearly production of 550 tons.

At \#5S, using a system called SIMA (an acronym, in Portuguese, for Integrated System for Environmental Monitoring; see Stech et al. 2006), the following meteorological parameters were measured at a height of $3 \mathrm{~m}$ : air temperature $\left(T_{\mathrm{a}}\right)$, relative humidity $\left(R_{\mathrm{h}}\right)$, atmospheric pressure $\left(P_{\mathrm{atm}}\right)$, wind speed $\left(U_{\mathrm{z}}\right)$ and direction, and shortwave radiation $\left(S_{\mathrm{w}}\right)$. From the SIMA (\#5S) and SIMA-Aquaculture (\#1C, \#2, \#3, \#4, and \#6), multiparameter sondes were installed, allowing measurement of water temperature $\left(T_{\mathrm{w}}\right)$, conductivity, $\mathrm{pH}$, turbidity, and DO concentration at a depth of $1.5 \mathrm{~m}$. Thermistor chains, which provided water temperature at different depths throughout the water column, were also installed in all systems. Each chain had 13 thermistors, distributed $0.25 \mathrm{~m}$ apart in the first meter, then $1 \mathrm{~m}$ apart in the next $5 \mathrm{~m}$, and finally every $2 \mathrm{~m}$ until $1 \mathrm{~m}$ above the bottom of the water column. A distinct difference between SIMA and SIMA-Aquaculture is that the first can transmit hourly-acquired data telemetrically in near real-time (excluding temperature from the thermistor chain), while the second can only store the data until a backup is conducted. Telemetric data was only used when downloaded data was not available. Table A1 in the Appendix describes the instruments used.

All instruments were configured to store data at regular intervals of $10 \mathrm{~min}$. Additionally, all wind direction data were corrected for magnetic declination for the FHR location using NOAA's magnetic field calculator (NOAA 2016).

SIMA and SIMA-Aquaculture operated from $\mathrm{Au}-$ gust 2013 to September 2015. However, due to battery recharging failure, from March 16 to May 10, 2014, no meteorological and WQP data were collected for \#5S. Furthermore, from December 10, 2014 until the end of the entire period, data from SIMA was not backed up (on a 10 min basis), and therefore only the telemetrically transmitted data (hourly based) were used.

Maintenance on the deployed equipment was conducted approximately every 2 mo. All sensors from the multiparameter sondes were submitted to a thorough calibration procedure according to the manufacturer's instructions. In case of unsuccessful calibration, data were considered unreliable, and we also disqualified any data collected when the measurement was taken outside of the calibration's lifetime, which is sensor-dependent. For the thermistor chains, data were discarded in 2 cases: (1) if the end of the chain's rope reached the bottom, which mainly happened during the drought of 2014, and (2) if the chain's rope was wrapped into the anchor's cable. Although these imposed restrictions in the usage of the water column temperature data, this was not critical for our analysis since temperature profiles among platforms were highly correlated. For example, the relationship between the temperature time series for a depth of $0.5 \mathrm{~m}$ collected by platforms \#1C and \#6 in February 2014 showed a determination coefficient $\left(R^{2}\right)$ of 0.85 and a root mean square error (RMSE) of $0.27^{\circ} \mathrm{C}$. Thus, for an overview of the temporal variation in the thermal structure of the water column, we used data from platforms \#1C, \#5S, and $\# 6$, to improve the temporal coverage.

\section{Rainfall and water level data}

Rainfall and reservoir water level data were computed for 2 periods: historical (or climatological) and the studied period. Monthly-accumulated precipitation data were acquired from a station located near the reservoir (municipality of Machado; $21.68^{\circ} \mathrm{S}$, $45.94^{\circ} \mathrm{W}$ ), downloaded from the National Institute of Meteorology database (INMET 2016). Historical precipitation data from 1961 to 2015 were used to compute monthly means. Daily reservoir water level data, in meters (a.m.s.l.), were acquired for the studied period. The historical reservoir level was computed from 1963 to 2015, with the data from 1963 to 2001 acquired on a monthly basis (maximum and minimum levels), and data from 2002 to 2015 on a daily basis. To compare both periods, monthly means were linearly interpolated to daily means to make it comparable to the data for the analyzed period.

\section{Surface heat flux balance and buoyancy frequency}

If we exclude the inflow and outflow contributions to the hydrodynamics of a water column, water temperature in the mixed layer and vertical stratification of a reservoir are controlled essentially by a combination of heat and wind mixing (Imberger \& Hamblin 
1982). While the surface heat flux balance $\left(S, \mathrm{~W} \mathrm{~m}^{-2}\right)$ acting over an aquatic system is one of the most important processes controlling the mixed layer dynamics (Henderson-Sellers 1986), the stability of the water column, or the buoyancy frequency $\left(N, \mathrm{~s}^{-1}\right)$, has been widely used as a metric for quantifying the stratification force (Marcé et al. 2000, Calijuri et al. 2002, Rao et al. 2008, Liu et al. 2012).

In this study, the meteorological variables measured by the SIMA, $T_{a l}, T_{w}, R_{h}, P_{a t m}$ and $U_{z 1}$ were used as inputs for the calculation of the components of $S$, on a 10 min basis. $S$ was computed following Eq. (1):

$$
S=S_{W}(1-\alpha)+L_{W}-(E+H)
$$

where $S_{W}$ is shortwave radiation (directly measured by the SIMA), $\alpha$ is the albedo of the shortwave radiation (calculated as in Martin \& McCutcheon 1999), $L_{W}$ is the net longwave radiation, and $E$ and $H$ are the turbulent fluxes of latent and sensible heat fluxes, respectively. Positive values of $S$, or net heat gain, indicate warming of the surface layer, which leads to more stability, while negative values, or net heat loss, indicate cooling of the surface layer and can promote vertical mixing. A complete description of the procedures to calculate the heat budget is found in Lorenzzetti et al. (2015).

Both emitted $\left(L_{w(e m i)}\right)$ and incident $\left(L_{w(i n c)}\right)$ longwave radiation $\left(L_{W}=L_{W(\text { inc })}-L_{W(e m i)}\right)$ were calculated following equations in Henderson-Sellers (1986). E and $H$ were estimated using the bulk aerodynamic transfer method, considering the stability of the atmospheric boundary layer (Amorocho \& DeVries 1980, Imberger \& Patterson 1990, Verburg \& Antenucci 2010).

Buoyancy frequency $(N)$ was calculated based on data from the thermistors chains, interpolated for regular intervals of $1 \mathrm{~m}$, as $N=[(-g / \bar{\rho})(\partial \rho / \partial z)]^{(1 / 2)}$, where $g$ is gravitational acceleration $\left(9.8 \mathrm{~m} \mathrm{~s}^{-2}\right), \bar{\rho}(\mathrm{kg}$ $\mathrm{m}^{-3}$ ) is mean density of the water column, and $\partial \rho / \partial z$ $\left(\mathrm{kg} \mathrm{m}^{-3} \mathrm{~m}^{-1}\right)$ is the density gradient. Water density was calculated as in Martin \& McCutcheon (1999), and the effects of salinity on density were considered negligible, since conductivity values were $<100 \mu \mathrm{S}$ $\mathrm{cm}^{-1}$. Positive values of $N$ indicate stable conditions, while negative and near-zero values indicate unstable and neutral conditions, respectively.

\section{CF identification}

Meteorological systems were identified as atmospheric disturbances that change the normal pattern of meteorological variables near the surface, such as at- mospheric pressure, air temperature and relative humidity, wind speed and direction, and the radiative components of the heat balance. An example of a meteorological system identification based on meteorological variables and satellite images is shown in Fig. 2.

Wind direction and air temperature were 2 key parameters for the identification of a $\mathrm{CF}$ passage (Fig. 2A,B). It was observed that the normal pattern of wind direction, from northerly to easterly, changes to southerly-southwesterly during a CF passage. Likewise, air temperature with a normal diel variation of $\sim 10^{\circ} \mathrm{C}$ was reduced to $\sim 3^{\circ} \mathrm{C}$.

Once changes in the normal pattern of the meteorological variables were identified, we used Geostationary Operational Environmental Satellite (GOES) images (Fig. 2C-E), previously processed by the Center for Weather Forecasting and Climate Research (CPTEC) of the National Institute of Space Research (CPTEC 2016), to confirm the CF passage, as shown in previous studies (Stech \& Lorenzzetti 1992, Tundisi et al. 2004). To better evaluate this identification, we also used monthly bulletins of climatic monitoring and analysis, provided by CPTEC (Climanálise 2016), which contain detailed information on atmospheric disturbances over Brazil.

\section{Critical conditions for Nile tilapia aquaculture}

Fish under production should be maintained at ideal environmental conditions for optimal development and growth. Thus, the collected WQP values in FHR were compared with ranges considered ideal for Nile tilapia farming. However, optimal ranges of WQPs vary according to the developmental phase of the fish. Since in the FHR, there were different developmental phases of Nile tilapia, we only considered optimal ranges described for young Nile tilapia, until more information becomes available in the literature.

While the optimum water temperature for Nile tilapia growth has been reported to be $\sim 30^{\circ} \mathrm{C}$ (Azaza et al. 2008), $27-30^{\circ} \mathrm{C}$ is also considered to be their thermal comfort zone (Boyd 1990, Ostrensky \& Boeger 1998, El-Sayed 2006). Outside of this range, fish are more apt to suffer from thermal stress and to develop diseases (Marcusso et al. 2015).

The recommended ranges of $\mathrm{pH}$ vary from 6.0-9.0 (Popma \& Masser 1999), 6.5-9.0 (Nandlal \& Pickering 2004), and 6.5-8.0 (Özdemir et al. 2014). Although these are small variations for optimal $\mathrm{pH}$, it was observed that the range 6.0-9.0 is important for proper fish development. Any $\mathrm{pH}$ value below or above this range will trigger biochemical and physi- 


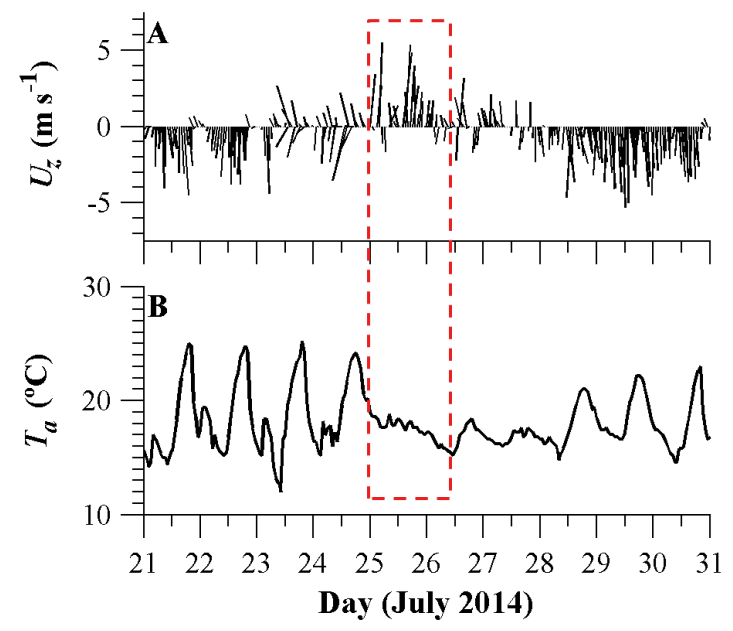

Fig. 2. Example of a cold front (CF) identified based on meteorological variables and satellite images. (A) The predominantly northerly wind direction changes to southerly $\left(U_{\mathrm{z}}\right.$ : wind speed) and (B) the normal diel variability of air temperature $\left(T_{\mathrm{a}}\right)$ is altered on July 25, 2014 (red dashed box) during a CF passage. A sequence of GOES images, on July (C) 23, (D) 24, and (E) 25, 2014 at 00:00 h, showing the displacement of a CF over the Furnas Hydroelectric Reservoir (red square)
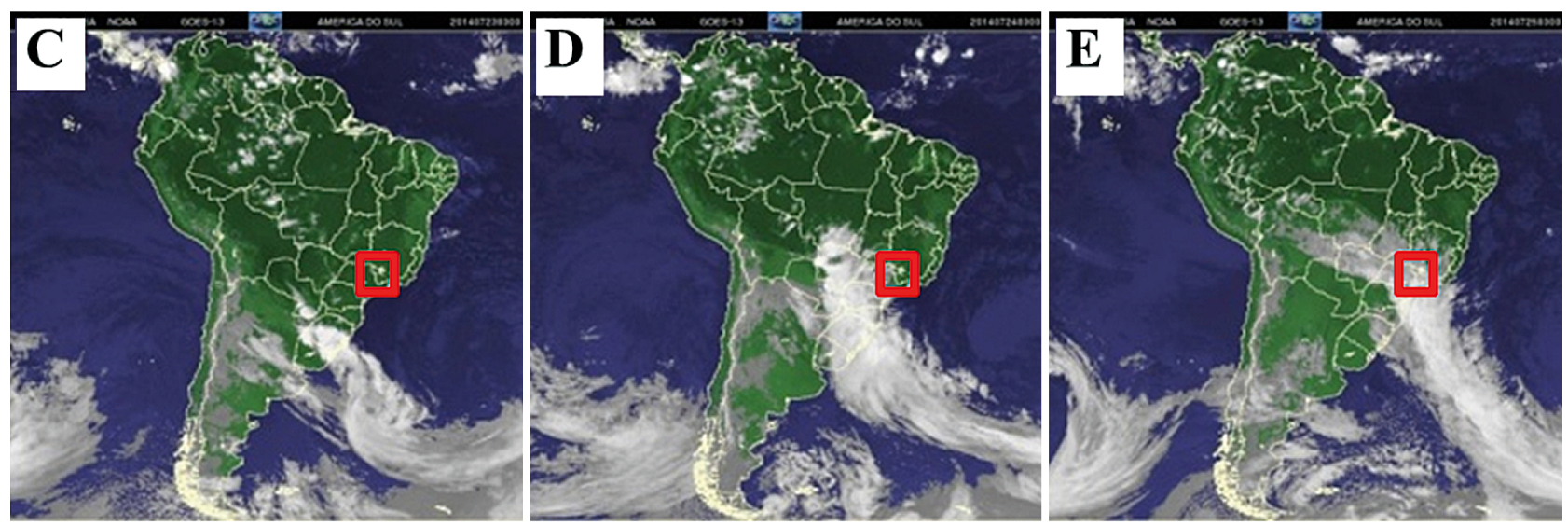

ological mechanisms to prevent death (Sampaio et al. 2010) .

Nile tilapia can be considered a resistant fish in terms of adverse environmental conditions. They can survive at DO concentrations as low as $1.0 \mathrm{mg} \mathrm{l}^{-1}$ (Abdel-Tawwab et al. 2015), so DO is not a limiting factor for their development. However, fish growth and feed efficiency are affected by low DO concentrations (Bergheim et al. 2006, Duan et al. 2011, Abdel-Tawwab et al. 2015), and contaminant-induced toxicity could increase at lower DO levels (Sampaio et al. 2012). Therefore, even if low DO concentration is not a significant threat to Nile tilapia, adequate DO levels should be maintained to satisfy functions responsible for improving fish performance and health (Abdel-Tawwab et al. 2015). Experiments exposing Nile tilapia to different DO concentrations showed that performance is better when concentrations vary from 6.0 to $6.5 \mathrm{mg} \mathrm{l}^{-1}$ than at lower levels (AbdelTawwab et al. 2015).

It is important to highlight that producers in the monitored areas of the FHR do not use any fish management procedures during the production cycle. Because of the lack of management, there is no record of fish development. However, during the analyzed period, a survey of fish physiological parameters was conducted, and results showed that fish under production were healthy.

\section{RESULTS}

FHR water level, precipitation, and seasonal characterization of water column temperature and stability

Monthly-accumulated precipitation and the FHR's water level data are presented in Fig. 3A for both the historical and analyzed periods. Time series of water column temperature and buoyancy frequency are shown in Fig. 3B,C (depth isopleths are in parallel to FHR water level). The analyzed period started on $\mathrm{Au}-$ gust 9, 2013 and ended on September 24, 2015 (Fig. 3).

The water level decreased remarkably, comparing the historical and analyzed periods. While the seasonal historical fluctuation in the water level ranges to about $4.5 \mathrm{~m}$, the fluctuation within the analyzed period ranged to about $11 \mathrm{~m}$. The below-normal water 

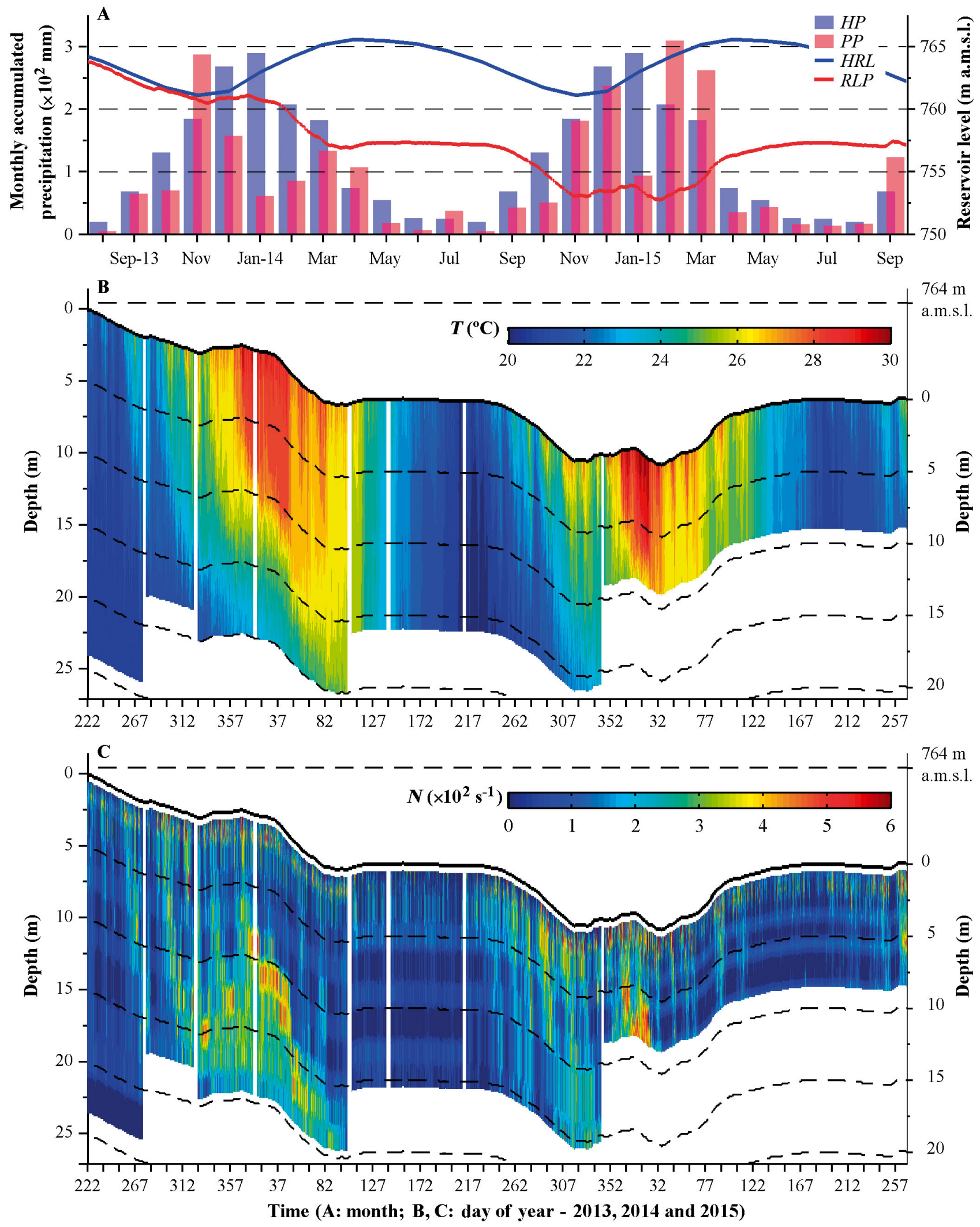

Fig. 3. Time series of (A) monthly mean accumulated precipitation (HP: averaged historical precipitation for 1961-2015, PP: precipitation in the analyzed period) and daily water level (HRL: averaged historical reservoir level for 1963-2015, $R L P$ : reservoir level in the analyzed period); (B) water column temperature $(T)$; and $(C)$ buoyancy frequency $(N)$. a.m.s.l.: above mean sea level 
level is strongly related to a drought period, which can also be observed in Fig. 3A. This drought occurred in the austral summers of 2013-2014 and 20142015 and affected FHR's water level as well as many other reservoirs in the southeast region of Brazil. This drought caused a severe problem in water supply management, especially in São Paulo-the largest city in Brazil (Escobar 2015, Meganck et al. 2015, Nobre et al. 2016). The cause of this 2 yr drought has been related to large-scale and regional atmospheric circulation, as well as sea surface temperature anomalies from the South Atlantic and Pacific oceans (Seth et al. 2015, Coelho et al. 2016). This can be better illustrated by the precipitation data, which showed that the difference between monthly-accumulated precipitation, from August 2013 to January 2015, and the averaged historical precipitation was $850 \mathrm{~mm}$.

Time series of the vertical thermal structure (Fig. 3B) revealed a strong seasonal pattern, with a well-marked period of stratification during the austral summer (approximately from day of the year [DOY] 300 to 100) and mixing during the austral winter (approximately from DOY 120 to 250). The buoyancy frequency data (Fig. 3C) confirmed these stratification-mixing patterns, with values reaching $0.07 \mathrm{~s}^{-1}$ in the stratification period. Based on this information and following Lewis' (1983) classification, the observed stratification-mixing pattern characterizes the FHR as a warm monomictic water body.

Water surface temperatures ranged from $31^{\circ} \mathrm{C}$ in the austral summer to $22^{\circ} \mathrm{C}$ in the austral winter, and at a depth of $\sim 16 \mathrm{~m}$, ranged from $26^{\circ} \mathrm{C}$ in summer to $20^{\circ} \mathrm{C}$ in winter. $N$ values had a strong diel signal in the first $5 \mathrm{~m}$, and they were observed in the entire time series. The seasonal behavior of $N$ shows high values in austral summers of 2013-2014 and 2014-2015, varying from 15 to $10 \mathrm{~m}$ depth. Although $N$ values $>0.05$ $\mathrm{s}^{-1}$ observed in the FHR are usually considered to be characteristic of a strong stratification, we observed neither a well-defined metalimnion nor a well-developed hypolimnion. Instead, a temperature gradient was present from the beginning of the metalimniom until the deepest parts of the water column.

\section{WQPs in stratification and mixing periods}

For practical purposes, an $N$ value of $0.03 \mathrm{~s}^{-1}$ was established as a threshold for the identification of stratification and mixing periods. Thus, hereinafter, reference to stratification and mixing pertains to the periods from November to March (DOY 305 to 90) and May to September (DOY 121 to 273), respec- tively. In these periods, water chemical property dynamics were driven partially by stratification and mixing regimes. Thus, time series of water $\mathrm{pH}, \mathrm{DO}$ concentration, and turbidity were separated into these 2 periods (Fig. 4). Minimum and maximum values and mean $(\bar{\mu})$ and standard deviation $(\sigma)$ for the same time series are shown in Table 1.

Mean water pH values were, in general, slightly higher when the water column was mixed rather than stratified. Comparing \#1C with the other platforms, mean values of $\mathrm{pH}$ were lower in those where fish cultivation was present. Additionally, higher ranges (Min-Max) and higher values of $\sigma$ were also observed at the platforms located in the aquaculture areas. These results indicate a distinction of processes acting naturally in the reservoir (\#1C) in comparison with the areas where Nile tilapia cages were present. During the water column stratification period, $\mathrm{pH}>8$ were observed for \#1C and \#3, while in the mixing period this was observed for \#1C and \#5S, with the mean $\mathrm{pH}$ also $>8$ on \#1C.

DO concentrations during the stratification regime were lower than those of the mixing regime for all platforms. This is partially explained by higher DO saturation values found during the mixing regime, which had a mean temperature of $\sim 22^{\circ} \mathrm{C}$, while the mean temperature during the stratification regime was of $\sim 28^{\circ} \mathrm{C}$. Mean values of DO concentrations were lower at platforms \#2, \#3, \#4, \#5S, and \#6 than at \#1C. Following the pattern of the $\mathrm{pH}$ values, higher ranges and $\sigma$ were observed in the cultivation areas (except $\sigma$ for \#2 in the mixing regime). Values $<4 \mathrm{mg} \mathrm{l}^{-1}$ for DO concentrations were found only in \#3 from both periods.

Specific conductance at $25^{\circ} \mathrm{C}$ values did not significantly vary between stratification-mixing periods or between platforms. The highest range of specific conductance was observed in \#6, from 33 to $51 \mu \mathrm{S}$ $\mathrm{cm}^{-1}$, while for \#1C it ranged from 35 to $45 \mu \mathrm{S} \mathrm{cm} \mathrm{cm}^{-1}$. Turbidity data presented several anomalous values, or spikes (e.g. Fig. 4K,L), which were associated with noise in the measurements. Therefore, the values obtained from all platforms were, in general, <10 NTU (excluding the spikes). The platforms installed in the cultivation area presented slightly higher values compared to the control site.

\section{CF effects on mixing and stratification patterns and WQPs}

Although several types of meteorological systems can affect water column stability, such as instability 


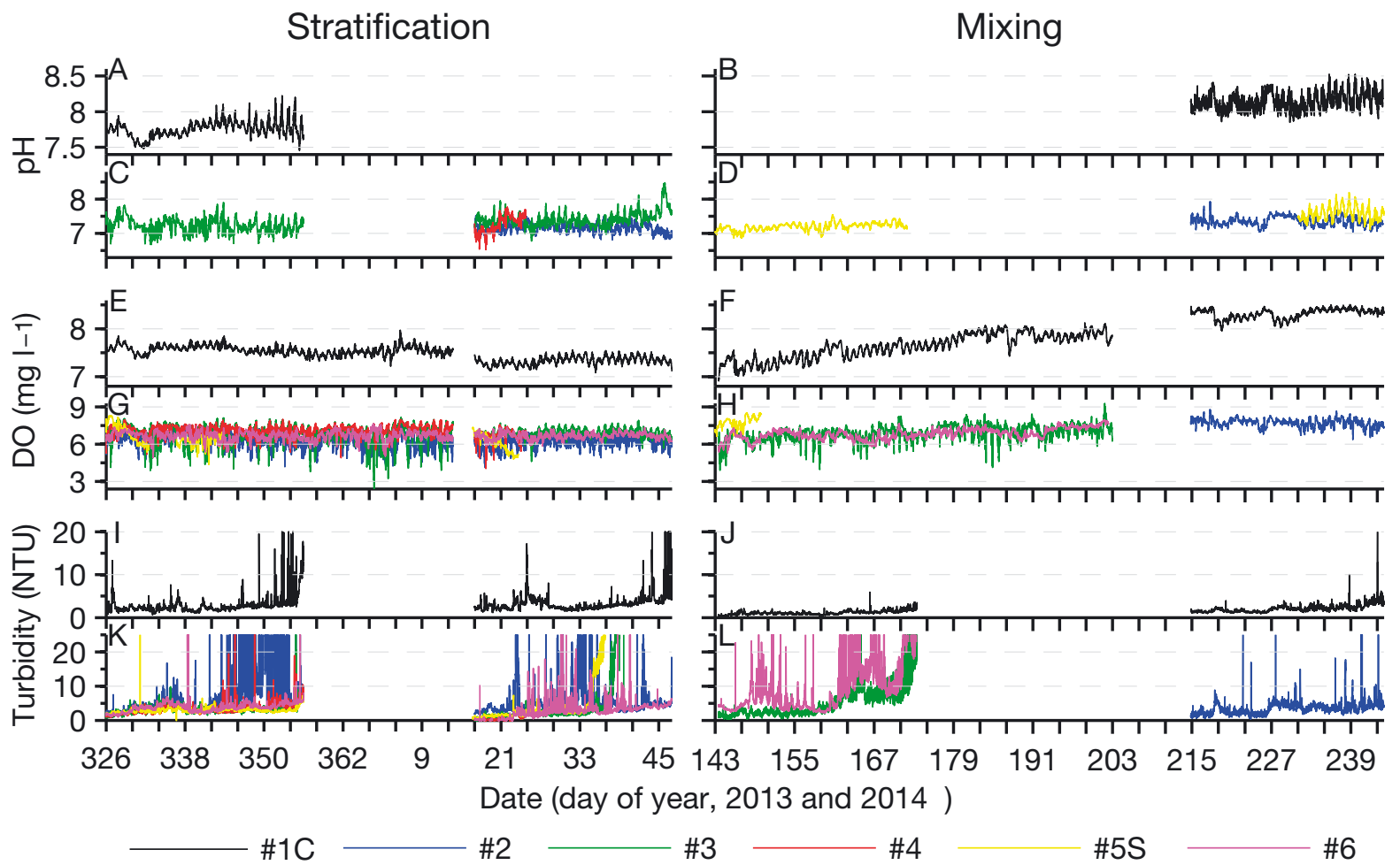

Fig. 4. Time series of $(\mathrm{A}-\mathrm{D})$ water $\mathrm{pH},(\mathrm{E}-\mathrm{H})$ dissolved oxygen $(\mathrm{DO})$, and $(\mathrm{I}-\mathrm{L})$ turbidity for the periods of stratification (left) and mixing (right) regimes at Furnas Hydroelectric Reservoir, for $(A, B, E, F, I, J)$ platform \#1C and $(C, D, G, H, K, L)$ platforms \#2, $\# 3, \# 4, \# 5 \mathrm{~S}$, and \#6

lines and conflict between masses (as shown by Ogashawara et al. 2014, for Guarapiranga reservoir, also in southeast Brazil), CF passages were the main meteorological systems associated with disturbances in the water column of FHR.

Twenty-four CF passages were identified acting over FHR during the analyzed period. Fig. 5 shows the days when those events occurred, superimposed with a daily integration of $S$. The density of CF occurrences was higher during the mixing period, with 17 passages, while during the stratification period, only 4 passages were identified (3 $\mathrm{CF}$ passages occurred in the transition between stratification and mixing periods). Daily integration values of $S$ varied from -220 to $205 \mathrm{~W} \mathrm{~m}^{-2}$, with positive values occurring with more frequency in the austral summer, and negative values occurring more frequently in the winter. The greatest daily net heat balance losses were associated with $\mathrm{CF}$ passages.

Wind direction and speed distribution, as well as the mean diel variability of $S$ and its components, were analyzed considering days with and without $\mathrm{CF}$ passages (Fig. 6). In general, days without the passage of $\mathrm{CF}$ were characterized by easterly (and fewer

Table 1. Minimum, maximum, mean $(\bar{\mu})$, and standard deviation $(\sigma)$ of $\mathrm{pH}$ and dissolved oxygen (DO) values of time series in Fig. 4. na: not available

\begin{tabular}{|c|c|c|c|c|c|c|c|c|c|c|c|c|c|}
\hline \multirow[t]{2}{*}{ Platform } & & \multicolumn{6}{|c|}{$-\mathrm{pH}$} & \multirow{2}{*}{$\# 1 \mathrm{C}$} & \multirow[b]{2}{*}{ \#2 } & \multicolumn{2}{|c|}{$-\mathrm{DO}$} & \multirow[b]{2}{*}{ \#5S } & \multirow[b]{2}{*}{ \#6 } \\
\hline & & $\# 1 \mathrm{C}$ & $\# 2$ & \#3 & \#4 & \#5S & \#6 & & & \#3 & $\# 4$ & & \\
\hline \multirow[t]{4}{*}{ Stratification } & Min. & 7.46 & 6.81 & 6.68 & 6.53 & na & na & 7.08 & 4.12 & 2.43 & 4.05 & 4.36 & 4.90 \\
\hline & Max. & 8.22 & 7.69 & 8.48 & 7.77 & na & na & 7.97 & 7.67 & 8.16 & 7.99 & 8.32 & 7.67 \\
\hline & $\bar{\mu}$ & 7.75 & 7.17 & 7.33 & 7.26 & na & na & 7.47 & 6.30 & 6.89 & 7.07 & 6.44 & 6.68 \\
\hline & $\sigma$ & 0.11 & 0.14 & 0.23 & 0.25 & na & na & 0.14 & 0.52 & 0.62 & 0.43 & 0.73 & 0.32 \\
\hline \multirow[t]{4}{*}{ Mixing } & Min. & 7.85 & 7.05 & na & na & 6.86 & na & 6.91 & 6.38 & 3.92 & na & 6.58 & 5.30 \\
\hline & Max. & 8.52 & 7.93 & na & na & 8.19 & na & 8.51 & 8.8 & 9.26 & na & 8.52 & 7.97 \\
\hline & $\bar{\mu}$ & 8.13 & 7.35 & na & na & 7.32 & na & 7.86 & 7.72 & 6.89 & na & 7.78 & 6.84 \\
\hline & $\sigma$ & 0.11 & 0.13 & na & na & 0.23 & na & 0.39 & 0.33 & 0.61 & na & 0.42 & 0.43 \\
\hline
\end{tabular}




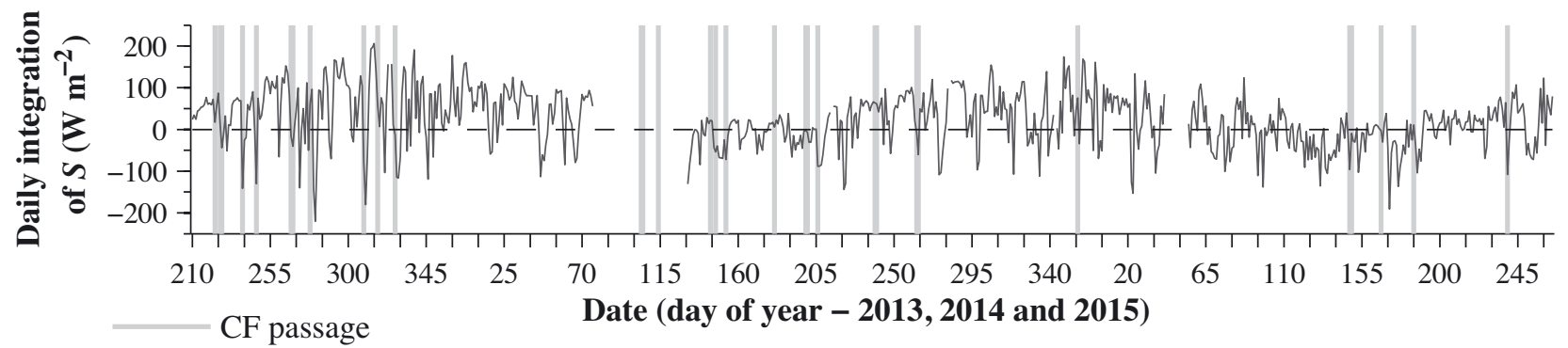

Fig. 5. Daily integration of surface heat flux balance $(S)$ at Furnas Hydroelectric Reservoir from July 2013 to September 2015. CF: cold front

northerly) winds, with speeds $<2 \mathrm{~m} \mathrm{~s}^{-1}$. In contrast, days with CF passages were characterized by southwesterly and westerly winds, with speeds $>3 \mathrm{~m} \mathrm{~s}^{-1}$. The mean diel variability of $S$ also showed different patterns for days with and without CF passages. On days without CF passages, the $S$ peak of heat gain was $509 \mathrm{~W} \mathrm{~m}^{-2}$, while on days with $\mathrm{CF}_{\text {, this peak }}$ dropped to around $394 \mathrm{~W} \mathrm{~m}^{-2}$. Integrating both diel variability of $S$ values, i.e. with and without CF passages (Fig. $6 \mathrm{C}, \mathrm{D}$ ), the obtained values were 25.22 and $-21.36 \mathrm{~W} \mathrm{~m}^{-2}$ for days with and without CF passages, respectively.

Since strong wind speeds and heat balance losses favor vertical mixing of the water column, it was expected that $\mathrm{CF}$ would alter the mixed layer dynamics. Fig. 7 shows the effects of CF passages on the

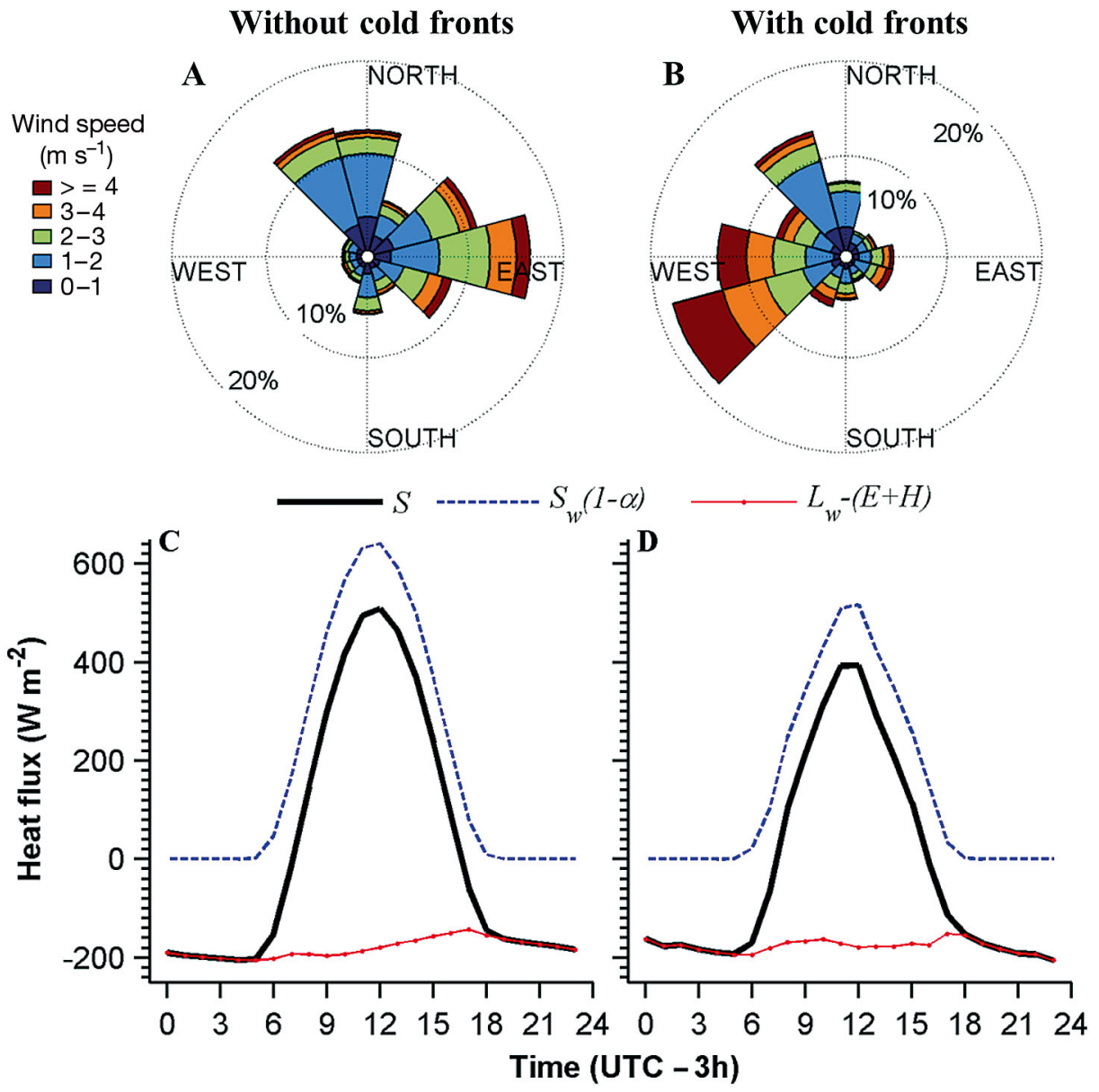

Fig. 6. (A,B) Wind direction and speed frequency distribution, and $(\mathrm{C}, \mathrm{D})$ diel variability of surface heat flux balance $(S)$, shortwave radiation $\left(S_{\mathrm{w}}\right)$ multiplied by 1 minus the albedo $(\alpha)$, and net longwave radiation $\left(L_{\mathrm{w}}\right)$ minus latent $(E)$ and sensible $(H)$ heat fluxes, for days $(\mathrm{A}, \mathrm{C})$ without and $(\mathrm{B}, \mathrm{D})$ with cold front passages 


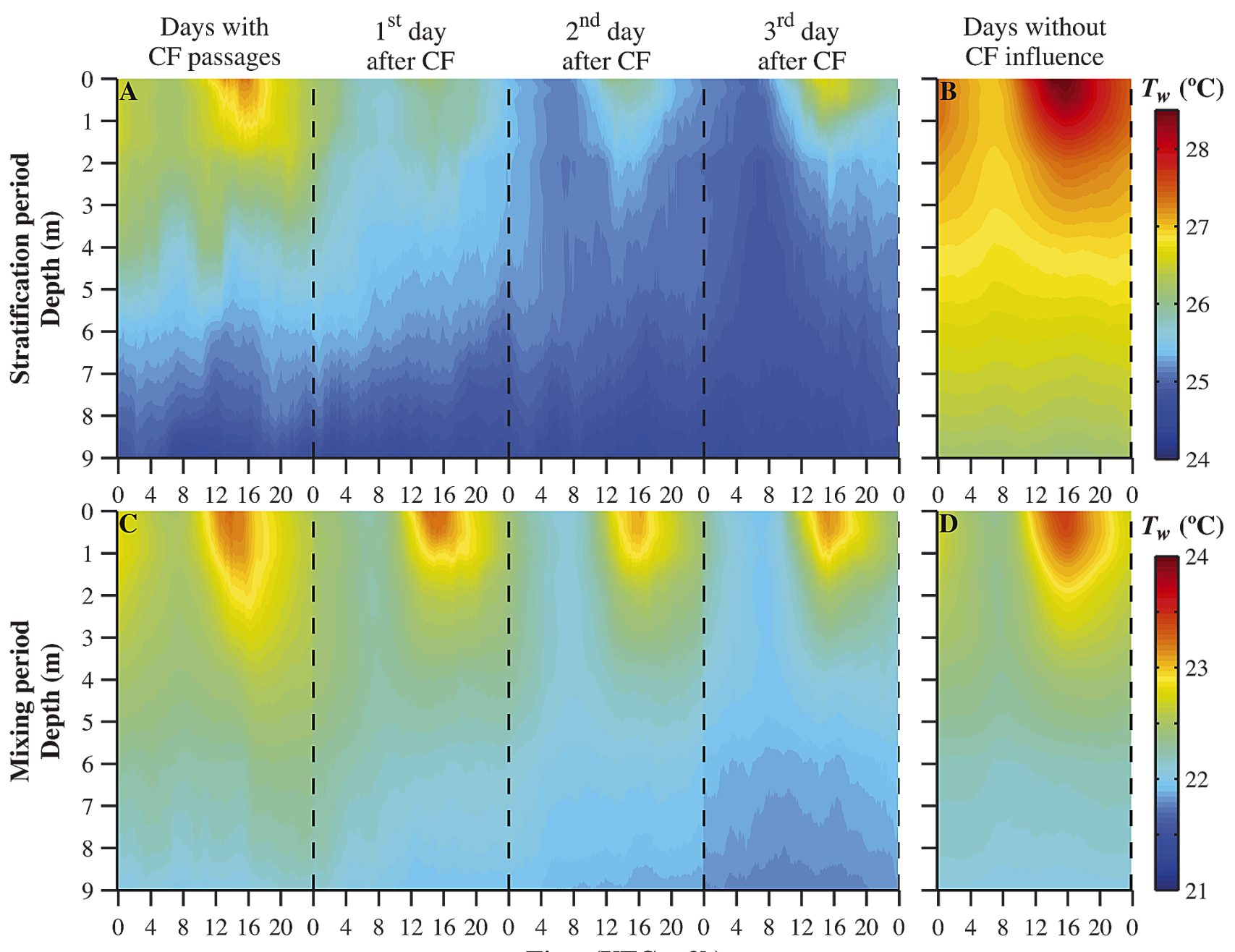

Time (UTC - 3h)

Fig. 7. Diel vertical distribution of water temperature $\left(T_{\mathrm{w}}\right)$ upon $(\mathrm{A}, \mathrm{C})$ occurrence of cold front $(\mathrm{CF})$ passages and $3 \mathrm{~d}$ afterwards, and $(B, D)$ without $C F$ influence, in periods of $(A, B)$ stratification and $(C, D)$ mixing

vertical structure of temperature, up to $9 \mathrm{~m}$ depth. The data were analyzed for both stratification and mixing periods, also considering days with and without $\mathrm{CF}$ influences. Additionally, measurements up to $3 \mathrm{~d}$ after $\mathrm{CF}$ passages were also considered. Fig. 7 displays means of the diel variability of temperature of the water column.

The mean diel pattern of temperature changes in the mixed layer of FHR is strongly related to the mean diel pattern of the heat flux balance. Both patterns showed higher values at 16:00 h (UTC $-3 \mathrm{~h}$ ) and minimum values at 07:00 h (UTC $-3 \mathrm{~h}$ ), which correspond to the end times of net heat gain and losses, respectively. In the stratification period, during a day with a CF passage and continuing for $3 \mathrm{~d}$ after its occurrence, colder water rises from the deepest parts of the reservoir to the upper layers (Fig. 7A). For normal conditions (without $\mathrm{CF}$ influences) in the stratification period, surface water temperature varied from 27 to $28.5^{\circ} \mathrm{C}$, while after a CF passage, this variation was from $25^{\circ} \mathrm{C}\left(07: 00 \mathrm{~h}\right.$ on the $3^{\text {rd }}$ day after the $\mathrm{CF}$ ) to $26^{\circ} \mathrm{C}\left(16: 00 \mathrm{~h}\right.$ on the $2^{\text {nd }}$ day after the $\left.\mathrm{CF}\right)$.

Deep, colder waters reached surface layers after $\mathrm{CF}$ passages during the mixing period (Fig. $7 \mathrm{C}$ ). For normal conditions, the temperature range was between 22.3 and $23.5^{\circ} \mathrm{C}$, while after a $\mathrm{CF}$ passage, the variation ranged from $21.9^{\circ} \mathrm{C}\left(07: 00 \mathrm{~h}\right.$ on the $3^{\text {rd }}$ day after the $\mathrm{CF})$ to $23^{\circ} \mathrm{C}\left(16: 00 \mathrm{~h}\right.$ on the $2^{\text {nd }}$ day after the $\mathrm{CF}$ ). Differences in the mean values between days with and without the influence of $\mathrm{CFs}$ during the mixing period was around $0.5^{\circ} \mathrm{C}$, in contrast to $2-2.5^{\circ} \mathrm{C}$ in the stratification period.

Vertical water temperature, buoyancy frequency,

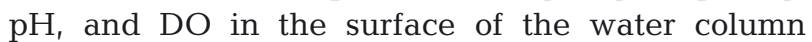
around a CF event, occurring on November 23, 2013 in the stratified period, are shown in detail in Fig. 8. 

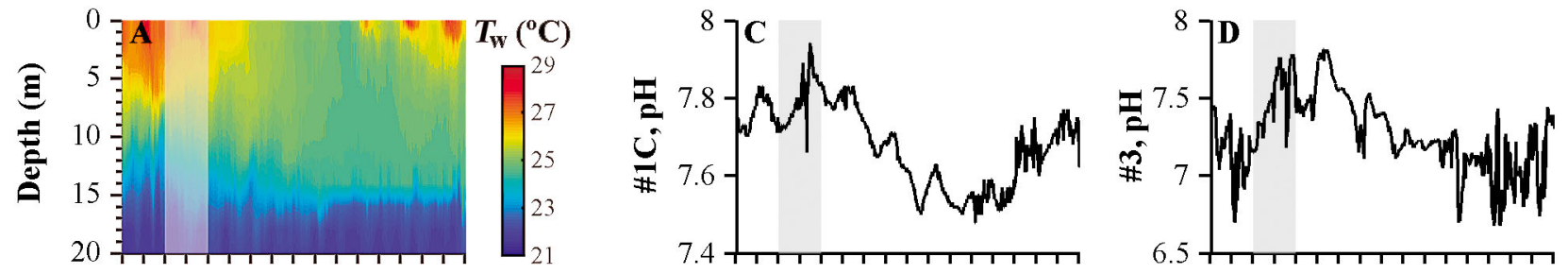

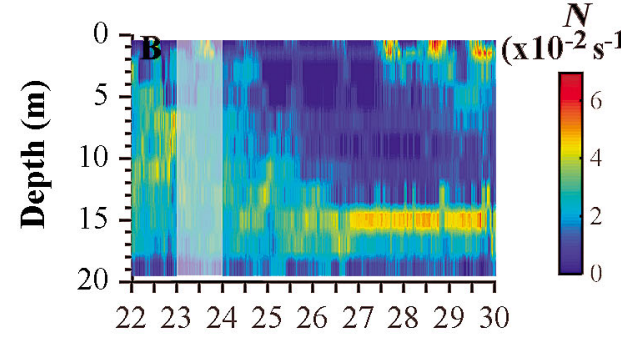

Time (dd, November 2013)

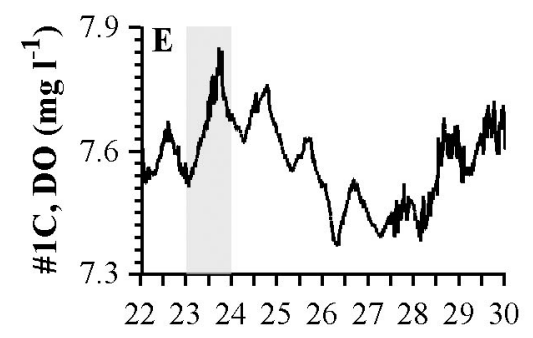

Time ( $d d$, November 2013)

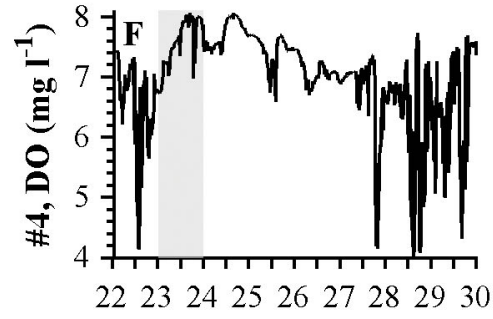

Time (dd, November 2013)

Fig. 8. Clipping of a short time-series of (A) water column temperature $\left(T_{\mathrm{w}}\right)$, (B) buoyancy frequency $(N),(\mathrm{C}, \mathrm{D}) \mathrm{pH}$ values at platforms \#1C and \#3, and (E,F) dissolved oxygen (DO) concentrations at platforms \#1C and \#4, around a cold front passage event on November 23, 2013 (highlighted in grey)

Before the CF passage, a strong gradient of temperature was observed from the first few meters $(\sim 2-4 \mathrm{~m})$ to $16-18 \mathrm{~m}$. Buoyancy frequency in this depth range was almost homogeneous, with a value of $0.04 \mathrm{~s}^{-1}$. During the passage of a $\mathrm{CF}$, the stratification weakens and, after approximately $1 \mathrm{~d}$, water temperature gradually becomes near-isothermal until approximately $13 \mathrm{~m}$ in depth. About $3-4 \mathrm{~d}$ after the passage, a strong stratification develops at about $15 \mathrm{~m}(0.05$ $\mathrm{s}^{-1}$ ), while the diel variability of temperature in the upper layer develops concomitantly.

At $\# 1 \mathrm{C}$, the results of the mixing effect of the $\mathrm{CF}$ passage caused a slight decrease in $\mathrm{pH}$ values and DO concentrations (Fig. 8C,E). The same pattern was observed for the other platforms, as exemplified by \#3 and \#4 (Fig. 8D,F). However, at these platforms, peaks of lower values for both $\mathrm{pH}$ and DO concentrations were observed without the influence of the CF. Nevertheless, since no WQPs ranged beyond acceptable values for Nile tilapia, fish productivity was considered normal, validated by the absence of mass mortality observations.

\section{DISCUSSION}

Water quality is a critical factor for any aquaculture activity, and the determination of the optimum range of WQPs for each species is important. Once these ranges are established, the monitoring of these WQPs is important to ensure growth and survival rates of the fishery. We discuss the relationships between changes in the monitored WQPs and CF passages as well as the significance of these changes to Nile tilapia farming.

The analyzed period can be considered anomalous because of the low water levels caused by drought. Drastic reductions in water levels are considered a major problem for net cage fish farming in large reservoirs, requiring changes in location, reorganization of infrastructures, and sometimes changes in equipment, which all increase the cost of production. In FHR, these anomalous meteorological conditions led to changes in the operations of Nile tilapia farming, such as changing of cage locations to promote the movement of water beneath them.

Although water level fluctuations may also lead to changes in nutrient concentration, plankton dynamics, and trophic state (Naselli-Flores \& Barone 1994, Naselli-Flores 2000, Geraldes \& Boavida 2005, da Costa et al. 2016), these were not observed to be a direct effect of the drought on the WQPs monitored in FHR.

A temperature gradient instead of a well-defined metalimnion in the stratification period, similar to the gradient that is characteristic for the FHR, was also observed in Foix Reservoir, Spain (Marcé et al. 2000), where a hypolimnion was not always present. In contrast, in the Barra Bonita Reservoir (southeast Brazil), weaker $N$ values (maximum of $0.027 \mathrm{~s}^{-1}$ in the summer) were reported, indicating that this reservoir is polymictic (Calijuri et al. 2002). In Lake Palminhas (southeast Brazil), which is a mesotrophic warm monomictic water body (Venturoti et al. 2015), during the mixing period (or dry season), the temperature and DO concentration differences between surface 
and deep layers $(\sim 20 \mathrm{~m})$ are minimum, $<1^{\circ} \mathrm{C}$ and $0.5 \mathrm{mg} \mathrm{l}^{-1}$ respectively. However, during the stratification period (or rainy season), these differences are about $4.5^{\circ} \mathrm{C}$ and $6.5 \mathrm{mg} \mathrm{l}^{-1}$ respectively, with the presence of an anoxic hypolimnion (Venturoti et al. 2014).

Water temperature is a crucial WQP for fish development, since it directly affects their growth (Martinez-Palacios et al. 1996, Azaza et al. 2008, 2010, El Sayed \& Kawanna 2008). Based on our results, the ideal period for Nile tilapia cultivation in the FHR seems to be the austral summer (stratification period), although water surface temperatures $>30^{\circ} \mathrm{C}$ may occur. On the other hand, during austral winter (mixing period), surface water temperatures $<22^{\circ} \mathrm{C}$ are extremely stressing for Nile tilapia. Although it has been reported that Nile tilapia can maintain their normal activity and survive $\sim 16^{\circ} \mathrm{C}$ (Sifa et al. 2002), at temperatures $<27^{\circ} \mathrm{C}$, fish will show reduced weight gain and increased disease susceptibility. Moreover, with the high frequency of CFs during this period, lower temperatures can be observed in the surface of the FHR. Therefore, it is recommended that workers avoid live fish handling and decrease fish density to prevent stress in this period of the year.

The increase of CF passages also increases FHR temperature fluctuation, which can also affect fish growth. Although the thermal fluctuation effect on Nile tilapia growth is not well understood, it has been demonstrated that it is size-dependent, allowing small juveniles to grow slightly faster but producing unsuitable conditions for fish of increasing size (Azaza et al. 2010). Therefore, the monitoring of meteorological systems can help to monitor aquaculture fields, since, with the higher density of CFs in the mixing period, thermal fluctuations will also increase.

Lower water $\mathrm{pH}$ levels and DO concentrations were found at all platforms located in the farming areas when compared to the control site. Oxygen depletion has a known effect on fish farming (Silvert 1992), caused by fish respiration as well as by the degradation process of organic matter, which can be higher within the cultivation areas due to uneaten food and excreta. Studies in Lake Palminhas (Venturoti et al. 2015) and FHR itself (Figueredo \& Giani 2005) agree with our results, i.e. alterations in $\mathrm{pH}$ and DO concentrations were observed within cultivation areas of Nile tilapia when compared with areas without cultivation.

One of the major environmental problems of using net cages in a water body is eutrophication due to fish waste in the surrounding area (Edwards 2015). In 2 experiments conducted in the FHR (at the begin- ning of the rainy and dry season) with enclosures containing Nile tilapia fish, Figueredo \& Giani (2005) verified that fish excretion increases the availability of nitrogen and phosphorus, which in turn promotes an increase in fast-growing algae. They also observed that selective feeding by Nile tilapia upon large algae (cyanobacteria and diatoms) controlled the relative abundance of phytoplankton species within the enclosures. In these 2 experiments, an initial decrease of both DO concentration and $\mathrm{pH}$ values was observed in relation to a control enclosure (no fish) and to another control point in the reservoir (no farming). Although the Nile tilapia contained in the enclosures in these experiments were not artificially fed (only naturally occurring plankton), the alterations in the water quality were noticeable. Therefore, the difference observed in water $\mathrm{pH}$ and $\mathrm{DO}$ concentration between \#1C and the other platforms can be tied to the absence or presence of net cages. Despite the observed influence of net cages on $\mathrm{pH}$ fluctuation, the measured $\mathrm{pH}$ was still within the ideal range for Nile tilapia cultivation. However, DO concentrations $<3.0 \mathrm{mg} \mathrm{l}^{-1}$ were observed in the FHR during the stratification period. Therefore, during this period, these low concentrations can be harmful for fish under production by decreasing their cost efficiency and increasing their stress susceptibility.

Low values of turbidity (excluding the noise) in this region of the FHR indicate that total suspended solids (TSS) concentrations are also low (since turbidity and TSS are highly correlated, e.g. Grayson et al. 1996, Bertrand-Krajewski 2004). TSS can be a limiting factor in light availability for primary production (e.g. Gikuma-Njuru \& Hecky 2005); however, this is not the case for the studied embayments of the FHR. The observed noise in turbidity measurement in our study was also identified in a monitoring program of hard clam aquaculture using the same multiparameter sonde (Bergquist et al. 2009). Therefore, future studies and monitoring programs should focus on understanding the cause of this noise in the turbidity sensor.

The occurrences of CFs over the FHR were more frequent during the austral winter than during the summer, confirming the expected climatology shown by previous studies (Stech \& Lorenzzetti 1992, Rodrigues et al. 2004). The combined effect of higher wind speeds and the increase in heat loss promoted by a $\mathrm{CF}$ acts in favor of mixing processes. Even though CFs occurred more intensively and more frequently during the austral winter, it is expected that changes in the environmental conditions of a water body due to a $\mathrm{CF}$ are more intense in the austral summer, when stratification is commonly established. 
Mixing of chemically divergent layers during a stratification period, or atelomixis (Lewis 1973), may occur on diel scales in the epilimnion, reflecting the diel variability of heat flux balance. Stronger variations are expected during and after CF passages, since they will promote partial or entire mixing of the water column. Atelomixis processes act as a fundamental factor for the controlling of vertical phytoplankton distribution and succession (Barbosa \& Padisák 2002). It is important to note that the physical processes associated with atelomixis may be related to basin-scale internal waves (Saggio \& Imberger 1998, Hingsamer et al. 2014). Thus, the variation caused by the passage of a CF (Fig. 7) over the FHR can play a key role in primary production dynamics. Although CFs significantly altered the temperature distribution in the water column (Fig. 8), they did not completely erode the stratification of the water column.

Nevertheless, in some stratified lakes and reservoirs, CFs can drastically reduce oxygen concentration in the surface by the upwelling of anoxic waters from the hypolimnion (Tundisi et al. 2010). Faxinal Reservoir (south Brazil) (Becker et al. 2009b), Barra Bonita Reservoir (Calijuri et al. 2002), and Lake Palminhas (southeastern Brazil) (Venturoti et al. 2014) are examples of water bodies where a hypolimnetic hypoxia (or even anoxia) is present. Therefore, in such water bodies, CF passages have the potential to promote the upwelling of these deep waters and significantly affect the water quality in the cultivation areas.

In this study, we did not observe any critical changes in WQPs that would adversely affect Nile tilapia cultivation. This could be explained by the absence of a well-developed hypolimnion and because CFs did not completely erode the stratification (in the stratification period). Instead, higher variability of WQPs in the cultivation areas was observed in comparison to the control site (\#1C) after a CF passage. Considering this effect, we observed that during the stratification period, 3 to $4 \mathrm{~d}$ after a $\mathrm{CF}$ passage, the water column had the ideal conditions for fish handling, since the effects of low $\mathrm{pH}$ and DO concentrations can be minimized by the dilution power promoted by the passage. The relatively low dilution power in the surface waters during the stratification period can lead to an increase in nutrient concentrations where the cages are present and, consequently, the phytoplankton ecological dynamics could be affected by these activities. Therefore, CF passages increase the embayments' dilution power by partially mixing the water column, benefiting the cultivation area in this region of the FHR.
The effects of CF passages over the FHR on water temperature (at $1.5 \mathrm{~m}$ depth), $\mathrm{DO}$, and $\mathrm{pH}$ values are summarized in Fig. 9. To look at an area outside the influence of the farms, the data shown in Fig. 9 are from our control site (\#1C). Although the mean temperature value in the stratification period decreases 2 or $3 \mathrm{~d}$ after the $\mathrm{CF}$ passages $\left(\sim 3^{\circ} \mathrm{C}\right)$, the mean of the other variables seems not to be highly affected, e.g. in a way that extrapolates the 1st and 3rd quartiles of days without $\mathrm{CFs}$ (exception of $\mathrm{DO}$ and $\mathrm{pH}$ values in the stratification periods).

The FHR, or at least the arm of the Grande River, can be considered suitable for Nile tilapia production. However, producers should consider that during the mixing periods, when temperatures are constantly $<27^{\circ} \mathrm{C}$, special management is needed. Since temperatures are outside the ideal range for the cultivation of Nile tilapia, producers should reduce fish density and fish manipulation to avoid fish stress. In this way, special management during mixing periods will allow them to maintain economic viability during the entire year.

We compare the WQPs in the FHR with the ideal range for 2 important native species in Brazilian aquaculture: tambaqui Colossoma macropomum and pacu Piaractus mesopotamicus. For tambaqui, the main challenge in the southeast and south regions of Brazil is its high sensitivity to low temperatures. In their natural habitat, tambaqui face temperatures varying from 25 to $40^{\circ} \mathrm{C}$, and temperatures $<20^{\circ} \mathrm{C}$ are adverse for their development. In terms of $\mathrm{pH}$, tambaqui develop better in acidic water, with $\mathrm{pH}$ values varying from 4 to 6 (Aride et al. 2007). Based on these optimal ranges, the natural alkaline waters in the FHR and mean temperatures constantly $>23^{\circ} \mathrm{C}$ during the mixing period may not be suitable for tambaqui cultivation.

On the other hand, pacu are more adapted to the southeast and south region of Brazil (Ferraz de Lima et al. 1988), since their ideal growing temperature is between 25 and $30^{\circ} \mathrm{C}$. Although they can resist lower temperatures $\left(15^{\circ} \mathrm{C}\right)$, the optimal range for their culture is $20-28^{\circ} \mathrm{C}$ (Saint-Paul 1989). An experimental study showed that a temperature of $7.5^{\circ} \mathrm{C}$ can be considered the lower limit for 1 yr old pacu survival (Milstein et al. 2000). The same study also stated that at temperatures under $16-18^{\circ} \mathrm{C}$, fish feeding can be suspended to avoid wasting.

The main challenge in cultivating native species in the FHR is the relatively low temperature that occurs during winter, which will force a reduction in the production. Therefore, the farming of hybrid fish species in net cages in southeast Brazil is increasing. In 


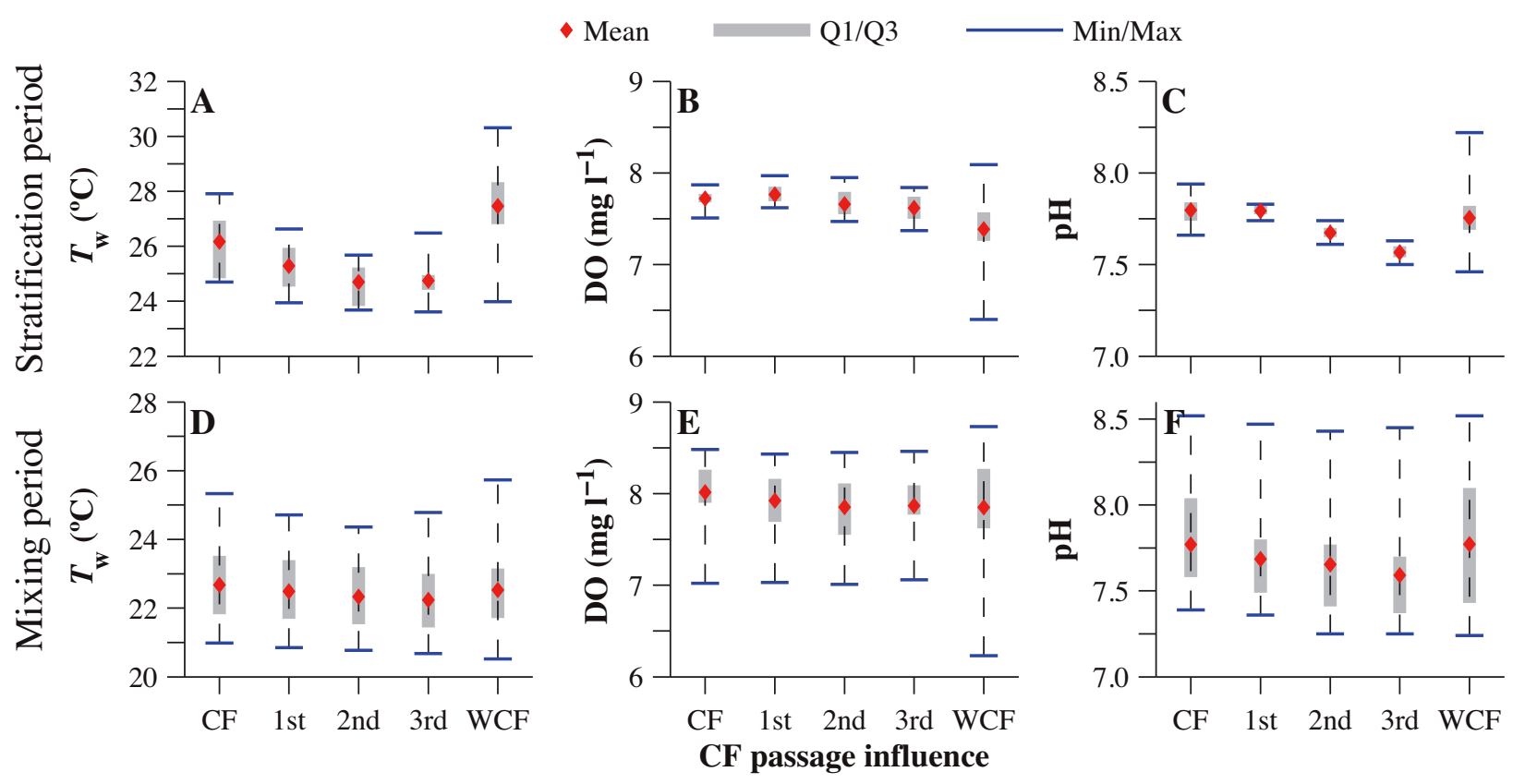

Fig. 9. Mean, $1^{\text {st }}$ quartile, $3^{\text {rd }}$ quartile, minimum, and maximum values of $(A, D)$ water temperature $\left(T_{\mathrm{w}}\right),(\mathrm{B}, \mathrm{E})$ dissolved oxygen (DO), and $(\mathrm{C}, \mathrm{F}) \mathrm{pH}$, at platform \#1C, for the $(\mathrm{A}-\mathrm{C})$ stratification and (D-F) mixing periods, on days without (WCF) and with $(\mathrm{CF})$ the influence of cold fronts (including the $1^{\text {st }}, 2^{\text {nd }}$, and $3^{\text {rd }}$ days after its passage)

this region, an alternative could be the production of hybrids such as tambacu (female C. macropomum $\times$ male P. mesopotamicus), which are more resistant to lower temperatures, or the tambatinga (female $C$. macropomum $\times$ male $P$. brachypomum), which has been produced in central-west Brazil with reliable results. However, so far there is no data available about the optimal range of WQPs for tambatinga culture. It is important to highlight that the culture of hybrid species should comply with Brazilian legislation (IBAMA Order no. 145 from 1998) regulating the usage of species to be farmed in Brazilian hydrographic basins.

The understanding of stratification and mixing patterns of an aquatic system and their influences on WQPs are fundamental for the identification of the effects on aquaculture activities and vice versa. The economic and social benefit of fish farming is undisputed, but proper management is required for longterm sustainable activities (Beveridge et al. 1997, Abery et al. 2005). In this work, the combination of meteorology, limnology, and aquaculture were successfully applied to the development of a framework for the enhanced management of a fishery. The role of CFs in stratification and mixing processes and the implications for Nile tilapia-based aquaculture farming located in the FHR were analyzed. A dataset of meteorological data, WQPs, and water column temperature time-series was used on a high temporal (continuous) acquisition basis, which was possible because of the use of moored platforms. Reliable data was able to be gathered due to the maintenance of the 6 moored platforms and their equipment. Despite the challenge to maintain moored systems for continuous acquisition of data (as previously noted in studies like Bergquist et al. 2009, Garel et al. 2009), the acquisition of high temporal resolution data for studies of lakes and reservoirs brings unprecedented knowledge of these environments in comparison to traditional fieldwork, where processes are addressed over short timeframes. For monitoring purposes, with an understanding of how meteorological systems affect heat flux balance and buoyancy frequency, the collection of meteorological variables could be reduced. Likewise, a thermistor chain could be deployed in only 1 representative location. Therefore, less effort would be needed to monitor WQPs in aquaculture fields.

The passage of CFs is a crucial factor to be considered in the monitoring of aquaculture activities in any water body. This may include, but is not limited to, south, southeast, and central-west regions of Brazil, as well as other countries in South America, like Argentina, Uruguay, and Paraguay. Although in this study, we highlighted the possible effects of CFs on aquaculture, it is important to note that other meteorological systems could also generate the same changes in the water column (Ogashawara et al. 
2014). For example, Curtarelli et al. (2014b) showed that mesoscale convective systems are important meteorological forces that act over the Tucuruí Reservoir, northern Brazil. Thus, it is important to identify the main meteorological system, or systems, acting over a water body when considering the installation of an aquaculture enterprise.

The rapid increase in Brazilian aquaculture production in the last 2 decades indicates a growing market for exotic and native species (Pincinato \& Asche 2016). Although the present study was restricted to Nile tilapia Oreochromis niloticus farming, which is considered a species that is highly tolerant to adverse environmental conditions, the proposed monitoring framework can be applicable to other fish cultures. The understanding and monitoring of the effects of CFs (and other meteorological systems) on different water bodies is highly important for the development of aquaculture and aquaculture policies worldwide.

Acknowledgements. This work is part of Furnas project, funded by the Ministry of Fisheries and Aquaculture of Brazil, and conducted in collaboration with the Brazilian Agricultural Research Corporation (Embrapa) and the National Institute for Space Research (INPE). C.A.S.A. thanks the National Council for Scientific and Technological Development (CNPq) for the PCI scholarship (Proc. no. 313071/2015-2). We thank Joaquim Leão and Geraldo Mendes for field assistance, and 3 anonymous reviewers for their suggestions to improve the manuscript.

\section{LITERATURE CITED}

Abdel-Tawwab M, Hagras AE, Elbaghdady HAM, Monier MN (2015) Effects of dissolved oxygen and fish size on Nile tilapia, Oreochromis niloticus (L.): growth performance, whole-body composition, and innate immunity. Aquacult Int 23:1261-1274

Abery NW, Sudaki F, Budhiman AA, Kartamihardja ES, Koeshendrajana S, Buddhiman, De Silva SS (2005) Fisheries and cage culture of three reservoirs in west Java, Indonesia; a case study of ambitious development and resulting interactions. Fish Manag Ecol 12:315-330

* Alcântara EH (2012) Accessing the potential of satellite and telemetric data to evaluate the influence of the heat flux exchange in the water column mixing and stratification. Int J Geosci 3:899-907

* Alcântara EH, Stech JL, Lorenzzetti JA, Bonnet MP, Casamitjana X, Assireu AT, Novo EMLM (2010) Remote sensing of water surface temperature and heat flux over a tropical hydroelectric reservoir. Remote Sens Environ 114:2651-2665

Amorocho J, DeVries JJ (1980) A new evaluation of the wind stress coefficient over water surfaces. J Geophys Res Oceans 85:433-442

Aride PHR, Roubach R, Val AL (2007) Tolerance response of tambaqui Colossoma macropomum (Cuvier) to water $\mathrm{pH}$. Aquacult Res 38:588-594
Azaza MS, Dhraïef MN, Kraïem MM (2008) Effects of water temperature on growth and sex ratio of juvenile Nile tilapia Oreochromis niloticus (Linnaeus) reared in geothermal waters in southern Tunisia. J Therm Biol 33: 98-105

Azaza MS, Legendre M, Kraiem MM, Baras E (2010) Sizedependent effects of daily thermal fluctuations on the growth and size heterogeneity of Nile tilapia Oreochromis niloticus. J Fish Biol 76:669-683

Barbosa FAR, Padisák J (2002) The forgotten lake stratification pattern: atelomixis, and its ecological importance. Verh Int Ver Limnol 28:1385-1395

* Becker V, Cardoso LS, Huszar VLM (2009a) Diel variation of phytoplankton functional groups in a subtropical reservoir in southern Brazil during an autumnal stratification period. Aquat Ecol 43:285-293

* Becker V, Huszar VLM, Crossetti LO (2009b) Responses of phytoplankton functional groups to the mixing regime in a deep subtropical reservoir. Hydrobiologia 628:137-151

* Bergheim A, Gausen M, Næss A, Hølland PM, Krogedal P, Crampton V (2006) A newly developed oxygen injection system for cage farms. Aquacult Eng 34:40-46

* Bergquist DC, Heuberger D, Sturmer LN, Baker SM (2009) Continuous water quality monitoring for the hard clam industry in Florida, USA. Environ Monit Assess 148: 409-419

*Bertrand-Krajewski JL (2004) TSS concentration in sewers estimated from turbidity measurements by means of linear regression accounting for uncertainties in both variables. Water Sci Technol 50:81-88

* Beveridge MCM, Phillips MJ, Macintosh DJ (1997) Aquaculture and the environment: the supply of and demand for environmental goods and services by Asian aquaculture and the implications for sustainability. Aquacult Res 28:797-807

Boyd CE (1990) Water quality for pond aquaculture. Auburn University, Auburn, AL

Boyd CE, Pillai VK (1985) Water quality management in aquaculture. Spec Publ, Vol 22. CMFRI (ICAR), Cochin

Calijuri MC, Dos Santos ACA, Jati S (2002) Temporal changes in the phytoplankton community structure in a tropical and eutrophic reservoir (Barra Bonita, S.P.Brazil). J Plankton Res 24:617-634

Cardoso EL, Gontijo VPM, Junior RMF, Morais ACR (2013) Ordenamento e monitoramento de áreas aquícolas do Reservatório de Furnas. Ser Doc 62. EPAMIG, Belo Horizonte

Climanálise (2016) Boletim de monitoramento e análise climática. www.climanalise.cptec.inpe.br/ rclimanl/boletim (accessed 1 July 2016)

Coelho CAS, Oliveira CP, Ambrizzi T, Reboita MS and others (2016) The 2014 southeast Brazil austral summer drought: regional scale mechanisms and teleconnections. Clim Dyn 46:3737-3752

CPTEC (Center for Weather Forecasting and Climate Research of the National Institute of Space Research) (2016) Collection BDI. www.cptec.inpe.br (accessed 1 Jul 2016)

* Curtarelli MP, Alcântara EH, Rennó CD, Stech JL (2013) Effects of cold fronts on MODIS-derived sensible and latent heat fluxes in Itumbiara reservoir (Central Brazil). Adv Space Res 52:1668-1677

Curtarelli MP, Alcântara EH, Rennó CD, Stech JL (2014a) Physical changes within a large tropical hydroelectric reservoir induced by wintertime cold front activity. Hydrol Earth Syst Sci 18:3079-3093 
Curtarelli MP, Ogashawara I, Araújo CAS, Alcântara EH, Lorenzzetti JA, Stech JL (2014b) Influence of summertime mesoscale convective systems on the heat balance and surface mixed layer dynamics of a large Amazonian hydroelectric reservoir. J Geophys Res Oceans 119: 8472-8494

da Costa MRA, Attayde JL, Becker V (2016) Effects of water level reduction on the dynamics of phytoplankton functional groups in tropical semi-arid shallow lakes. Hydrobiologia 778:75-89

Duan Y, Dong X, Zhang X, Miao Z (2011) Effects of dissolved oxygen concentration and stocking density on the growth, energy budget and body composition of juvenile Japanese flounder, Paralichthys olivaceus (Temminck et Schlegel). Aquacult Res 42:407-416

Edwards P (2015) Aquaculture environment interactions: past, present and likely future trends. Aquaculture 447: $2-14$

El-Sayed AFM (2006) Tilapia culture. CABI Publishing, Wallingford

El-Sayed AFM, Kawanna M (2008) Optimum water temperature boosts the growth performance of Nile tilapia (Oreochromis niloticus) fry reared in a recycling system. Aquacult Res 39:670-672

Escobar H (2015) Drought triggers alarms in Brazil's biggest metropolis. Science 347:812

FAO (Food and Agriculture Organization ot the United Nations) (2016) The state of world fisheries and aquaculture 2016 (SOFIA). Contributing to food security and nutrition for all. FAO, Rome

Ferraz de Lima JA, Ferrari VA, Colares de Melo JS (1988) Comportamento do pacu em um cultivo experimental, no centro oeste do Brasil. Bol Tec CEPTA 1:15-28

Figueredo CC, Giani A (2005) Ecological interactions between Nile tilapia (Oreochromis niloticus, L.) and the phytoplanktonic community of the Furnas Reservoir (Brazil). Freshw Biol 50:1391-1403

Furnas (2016) Parque Gerador: usina hidrelétrica de Furnas. www.furnas.com.br (accessed 29 Sep 2016)

* Ganf GG (1974) Diurnal mixing and the vertical distribution of phytoplankton in a shallow equatorial lake (Lake George, Uganda). J Ecol 62:611-629

Garel E, Nunes S, Neto JM, Fernandes R, Neves R, Marques JC, Ferreira Ó (2009) The autonomous Simpatico system for real-time continuous water-quality and current velocity monitoring: examples of application in three Portuguese estuaries. Geo-Mar Lett 29:331-341

Garreaud RD (2000) Cold air incursion over subtropical South America: mean structure and dynamics. Mon Weather Rev 128:2544-2559

Geraldes AM, Boavida MJ (2005) Seasonal water level fluctuations: implications for reservoir limnology and management. Lakes Reservoirs: Res Manage 10:59-69

Gikuma-Njuru P, Hecky RE (2005) Nutrient concentrations in Nyanza Gulf, Lake Victoria, Kenya: light limits algal demand and abundance. Hydrobiologia 534:131-140

Grayson RB, Finlayson BL, Gippel CJ, Hart BT (1996) The potential of field turbidity measurements for the computation of total phosphorus and suspended solids loads. J Environ Manage 47:257-267

Henderson-Sellers B (1986) Calculating the surface energy balance for lake and reservoir modelling: a review. Rev Geophys 24:625-649

Hingsamer P, Peeters F, Hofmann H (2014) The consequences of internal waves for phytoplankton focusing on the distribution and production of Planktothrix rubensces. PLOS ONE 9:e104359

IBGE (Brazilian Institute of Geography and Statistics) (2016) Produção da pecuária municipal 2015, Vol 43, IBGE, Produção da Pecuária Minicipal, Rio de Janeiro, p 1-49. https://biblioteca.ibge.gov.br/visualizacao/periodicos/84/ ppm_2015_v43_br.pdf (accessed 3 Oct 2016)

Imberger J, Hamblin PF (1982) Dynamics of lakes, reservoirs, and cooling ponds. Annu Rev Fluid Mech 14:153-187

Imberger J, Patterson JC (1990) Physical limnology. Adv Appl Mech 27:303-475

INMET (National Institute of Meteorology) (2016) Banco de dados meteorológicos para ensino e pesquisa. www. inmet.gov.br (accessed $10 \mathrm{Jul} 2016$ )

Jobling M (1994) Fish bioenergetics. Chapman \& Hall, London

Kapetsky JM (2000) Present applications and future needs of meteorological and climatological data in inland fisheries and aquaculture. Agric For Meteorol 103:109-117

Kewis WM Jr (1973) The thermal regime of Lake Lanao (Philippines) and its theoretical implications for tropical lakes. Limnol Oceanogr 18:200-217

KLewis WM Jr (1983) A revised classification of lakes based on mixing. Can J Fish Aquat Sci 40:1779-1787

Liu H, Zhang Y, Liu S, Jiang H, Sheng L, Williams QL (2009) Eddy covariance measurements of surface energy budget and evaporation in a cool season over southern open water in Mississippi. J Geophys Res Atmos 114:D04110

* Liu L, Liu D, Johnson DM, Yi Z, Huanh Y (2012) Effects of vertical mixing on phytoplankton blooms in Xiagxi Bay of Three Gorges Reservoir: implications for management. Water Res 46:2121-2130

Korenzzetti JA, Araújo CAS, Curtarelli MP (2015) Mean diel variability of surface energy fluxes over Manso Reservoir. Inland Waters 5:155-172

Marcé R, Comerma M, Garcia JC, Gomà J, Armengol J (2000) Limnology of Foix Reservoir (Barcelona, Spain). Limnetica 19:175-191

* Marcusso PF, Aguinaga JY, Claudiano GS, Eto SF and others (2015) Influence of temperature on Streptococcus agalactiae infection in Nile tilapia. Braz J Vet Res Anim Sci 52:57-62

Martin JL, McCutcheon SC (1999) Hydrodynamics and transport for water quality modeling. CRC Press, Boca Raton, FL

Martinez-Palacios CA, Chavez-Sanchez MC, Ross LG (1996) The effects of water temperature on food intake, growth and body composition of Cichlasoma urophthalmus (Günther) juveniles. Aquacult Res 27:455-461

*Meganck R, Havens K, Pinto-Coelho RM (2015) Water: megacities running dry in Brazil. Nature 521:289

Milstein A, Zoran M, Peretz Y, Joseph D (2000) Low temperature tolerance of pacu, Piaractus mesopotamicus. Environ Biol Fishes 58:455-460

MPA (Ministry of Fisheries \& Aquaculture of Brazil) (2013) Boletim estatístico da pesca e aquicultura 2011. MPA, Brasília. www.icmbio.gov.br/cepsul/images/stories/ biblioteca/download/estatistica/est_2011_bol__bra.pdf (accessed 29 Sep 2016)

Nandlal S, Pickering T (2004) Tilapia hatchery Operation. In: Tilapia fish farming in Pacific Island countries, Vol 1. University of the South Pacific, Noumea

Naselli-Flores L (2000) Phytoplankton assemblages in twentyone Sicilian reservoirs: relationships between species composition and environmental factors. Hydrobiologia 
424:1-11

Naselli-Flores L, Barone R (1994) Relationship between trophic state and plankton community structure in 21 Sicilian dam reservoirs. Hydrobiologia 275/276:197-205

NOAA (2016) Magnetic field calculators. www.ngdc.noaa. gov/geomag-web (accessed 5 Jun 2016)

Nobre CA, Marengo JA, Seluchi ME, Cuartas AL, Alves LM (2016) Some characteristics and impacts of the drought and water crisis in southeastern Brazil during 2014 and 2015. J Water Resour Prot 8:252-262

Ogashawara I, Zavattini JA, Tundisi JG (2014) The climatic rhythm and blooms of cyanobacteria in a tropical reservoir in São Paulo, Brazil. Braz J Biol 74:72-78

Ostrensky A, Boeger W (1998) Piscicultura: fundamentos e técnicas de manejo. Agropecuária, Guaíba

Özdemir N, Demirak A, Keskin F (2014) Quality of water used during cage cultivation of rainbow trout (Oncorhynchus mykiss) in Bereket HES IV Dam Lake (Muğla, Turkey). Environ Monit Assess 186:8463-8472

Pincinato RBM, Asche F (2016) The development of Brazilian aquaculture: introduced and native species. Aquacult Econ Manage 20:312-323

Pollock MS, Clarke LMJ, Dubé MG (2007) The effects of hypoxia on fishes: from ecological relevance to physiological effects. Environ Rev 15:1-14

Popma T, Masser M (1999) Tilapia: life history and biology. SRAC Publ No. 283. Southern Regional Aquaculture Center, Stoneville, MS

Rao YR, Hawley N, Charlton MN, Schertzer WM (2008) Physical processes and hypoxia in the central basin of Lake Erie. Limnol Oceanogr 53:2007-2020

Reynolds CS (1992) Dynamics, selection and composition of phytoplankton in relation to vertical structure in lakes. Arch Hydrobiol Beih Ergeb Limnol 35:13-31

Rodrigues MLG, Franco D, Sugahara S (2004) Climatologia de frentes frias no litoral de Santa Catarina. Rev Bras Geofís 22:135-151

Saggio A, Imberger J (1998) Internal wave weather in a stratified lake. Limnol Oceanogr 43:1780-1795

Saint-Paul U (1989) Aquaculture in Latin America. Indigenous species promise increased yields. Naga IGLARM Q 12:3-5

Sampaio FG, Boijink CL, Santos LRB, Oba ET, Kalinin AL, Rantin FT (2010) The combined effect of copper and low $\mathrm{pH}$ on antioxidant defenses and biochemical parameters in neotropical fish pacu, Piaractus mesopotamicus (Holmberg, 1887). Ecotoxicology 19:963-976

Sampaio FG, Boijink CL, Santos LRB, Oba ET, Kalinin AL, Luiz AJB, Rantin FT (2012) Antioxidant defenses and biochemical changes in pacu, Piaractus mesopotamicus: responses to single and combined copper and hypercarbia exposure. Comp Biochem Physiol C 156:178-186

Serra T, Vidal J, Casamitjana X, Soler M, Colomer J (2007) The role of surface vertical mixing in phytoplankton distribution in a stratified reservoir. Limnol Oceanogr 52: 620-634

* Seth A, Fernandes K, Camargo SJ (2015) Two summers of São Paulo drought: origins in the western tropical Pacific. Geophys Res Lett 42:10816-10823

Sifa L, Chenhong L, Dey M, Gagalac F, Dunham R (2002) Cold tolerance of three strains of Nile tilapia, Oreochromis niloticus, in China. Aquaculture 213:123-129

Silvert W (1992) Assessing environmental impacts of finfish aquaculture in marine waters. Aquaculture 107:67-79

* Stech JL, Lorenzzetti JL (1992) The response of the South Brazil Bight to the passage of wintertime cold fronts. J Geophys Res Oceans 97:9507-9520

Stech JL, Lima IBT, Novo EMLM, Silva CM and others (2006) Telemetric monitoring system for meteorological and limnological data acquisition. Verh Int Ver Limnol 29:1747-1750

* Tundisi JG, Matsumura-Tundisi T, Arantes JD Jr, Tundisi JEM, Manzini NF, Ducrot R (2004) The response of Carlos Botelho (Lobo, Broa) reservoir to the passage of cold fronts as reflected by physical, chemical and biological variables. Braz J Biol 64:177-186

* Tundisi JG, Matsumura-Tundisi T, Pereira KC, Luzia AP and others (2010) Cold fronts and reservoir limnology: an integrated approach towards the ecological dynamics of freshwater ecosystems. Braz J Biol 70:815-824

*van Rijssel JC, Hecky RE, Kishe-Machumu MA, Meijer SE and others (2016) Climatic variability in combination with eutrophication drives adaptive responses in the gills of Lake Victoria cichlids. Oecologia 182:1187-1201

Venturoti GP, Veronez AC, Salla RV, Gomes LC (2014) Phosphorous, total ammonia nitrogen and chlorophyll a from fish cages in a tropical lake (Lake Plaminhas, Espirito Santo, Brazil). Aquacult Res 2014:1-15

* Venturoti GP, Veronez AC, Salla RV, Gomes LC (2015) Variation of limnological parameters in a tropical lake used for tilapia cage farming. Aquacult Rep 2:152-157

* Verburg P, Antenucci JP (2010) Persistent unstable atmospheric boundary layer enhances sensible and latent heat loss in a tropical great lake: Lake Tanganyika. J Geophys Res Atmos 115:D11109

*Vidal J, Moreno-Ostos E, Escot C, Quesada R, Rueda F (2010) The effects of diel changes in circulation and mixing on the longitudinal distribution of phytoplankton in a canyon-shaped Mediterranean reservoir. Freshw Biol 55: 1945-1957 


\section{Appendix.}

Table A1. Meteorological and water quality parameters collected by Integrated System for Environmental Monitoring (SIMA) and SIMA-Aquaculture at the 6 platforms (see Fig. 1C)

\begin{tabular}{|c|c|c|c|c|}
\hline Data & Unit & Manufacturer and model & Range; accuracy & Platform \\
\hline Air temperature $\left(T_{a}\right)$ & ${ }^{\circ} \mathrm{C}$ & \multirow[t]{2}{*}{ Rotronic MP 101A } & -40 to $60 ; \pm 0.3$ & \multirow[t]{2}{*}{ \#5S } \\
\hline Relative humidity $\left(R_{\mathrm{h}}\right)$ & $\%$ & & 0 to $100 ; \pm 1$ & \\
\hline Atmospheric pressure $\left(P_{\mathrm{atm}}\right)$ & $\mathrm{hPa}$ & Vaisala PTB 110 & 800 to $1060 ; \pm 0.3$ at $20^{\circ} \mathrm{C}$ & \#5S \\
\hline $\begin{array}{l}\text { Wind speed }\left(U_{\mathrm{z}}\right) \\
\text { Wind direction }\end{array}$ & $\begin{array}{l}\mathrm{m} \mathrm{s}^{-1} \\
\text { degrees }\end{array}$ & RM Young 05106 & $\begin{array}{c}0 \text { to } 100 ; \pm 0.3 \\
0 \text { to } 360 ; \pm 3\end{array}$ & $\# 5 \mathrm{~S}$ \\
\hline Shortwave radiation $\left(S_{\mathrm{w}}\right)$ & $\mathrm{W} \mathrm{m^{-2 }}$ & Novalynx 840-8102 & 0 to $1500_{;}<1$ & \multirow[t]{2}{*}{ \#5S } \\
\hline Multiparameter sonde: & - & YSI 6600 V2-4 (or V2-2) ${ }^{\mathrm{a}}$ & - & \\
\hline Water temperature $\left(T_{\mathrm{w}}\right)$ & ${ }^{\circ} \mathrm{C}$ & \multirow[t]{2}{*}{ YSI 6560} & -5 to $60 ; \pm 0.15$ & \multirow{3}{*}{$\begin{array}{l}\# 1 \mathrm{C}, \# 2, \# 3, \# 4 \\
\# 5 \mathrm{~S} \text {, and \#6 }\end{array}$} \\
\hline Conductivity & $\mathrm{mS} \mathrm{cm}^{-1}$ & & $\begin{array}{l}0 \text { to } 100 ; \pm 0.5 \% \text { of } \\
\text { reading }+0.001\end{array}$ & \\
\hline $\mathrm{pH}$ & - & YSI 6561 & 0 to $14 ; \pm 0.2$ & \\
\hline Turbidity & NTU & YSI 6136 & $\begin{array}{c}0 \text { to } 1000 ; \pm 2 \% \text { of reading or } 0.3 \\
\text { (whichever is greater) }\end{array}$ & $\begin{array}{l}\# 1 \mathrm{C}, \# 2, \# 3, \# 4 \text {, } \\
\quad \# 5 \mathrm{~S} \text {, and \#6 }\end{array}$ \\
\hline Dissolved oxygen (DO) & $\mathrm{mg} \mathrm{l}^{-1}$ & YSI 6150 (or YSI 6562) & $\begin{array}{c}0 \text { to } 50 ; \pm 0.1(0.2) \text { or } 1 \%(2 \%) \\
\text { of reading (whichever is greater) }\end{array}$ & $\begin{array}{l}\# 1 \mathrm{C}, \# 2, \# 3, \# 4 \text {, } \\
\# 5 \mathrm{~S} \text {, and \#6 }\end{array}$ \\
\hline \multicolumn{5}{|l|}{ Thermistor chain: } \\
\hline Water temperature $\left(T_{\mathrm{w}}\right)$ & ${ }^{\circ} \mathrm{C}$ & $\begin{array}{l}\text { Onset HOBO U22-01 } \\
\text { Water Temp Pro v2 }\end{array}$ & -40 to $50 ; \pm 0.2$ & $\begin{array}{l}\# 1 \mathrm{C}, \# 2, \# 3, \# 4 \text {, } \\
\# 5 \mathrm{~S} \text {, and \#6 }\end{array}$ \\
\hline
\end{tabular}

Editorial responsibility: Craig Stevens, Wellington, New Zealand
Submitted: October 20, 2016; Accepted: July 28, 2017

Proofs received from author(s): September 16, 2017 